University of Nebraska - Lincoln

DigitalCommons@University of Nebraska - Lincoln

$5-1985$

\title{
Magnetic Polarity Stratigraphy And Mammalian Fauna Of The Deseadan (Late Oligocene-Early Miocene) Salla Beds Of Northern Bolivia
}

\author{
Bruce J. Macfadden \\ University of Florida, Gainesville \\ Kenneth E. Campbell Jr. \\ Natural History Museum of Los Angeles County \\ Richard L. Cifelli \\ National Museum of National History \\ Oscar Siles \\ Servicio Geol6gico de Bolivia \\ Noye M. Johnson \\ Dartmouth College \\ See next page for additional authors \\ Follow this and additional works at: https://digitalcommons.unl.edu/usgsstaffpub \\ Part of the Earth Sciences Commons
}

Macfadden, Bruce J.; Campbell, Kenneth E. Jr.; Cifelli, Richard L.; Siles, Oscar; Johnson, Noye M.; Naeser, Charles W.; and Zeitler, Peter K., "Magnetic Polarity Stratigraphy And Mammalian Fauna Of The Deseadan (Late Oligocene-Early Miocene) Salla Beds Of Northern Bolivia" (1985). USGS Staff -- Published Research. 496.

https://digitalcommons.unl.edu/usgsstaffpub/496

This Article is brought to you for free and open access by the US Geological Survey at DigitalCommons@University of Nebraska - Lincoln. It has been accepted for inclusion in USGS Staff -- Published Research by an authorized administrator of DigitalCommons@University of Nebraska - Lincoln. 


\section{Authors}

Bruce J. Macfadden, Kenneth E. Campbell Jr., Richard L. Cifelli, Oscar Siles, Noye M. Johnson, Charles W. Naeser, and Peter K. Zeitler 


\title{
THE JOURNAL OF GEOLOGY
}

May 1985

\author{
MAGNETIC POLARITY STRATIGRAPHY AND MAMMALIAN FAUNA \\ OF THE DESEADAN (LATE OLIGOCENE-EARLY MIOCENE) \\ SALLA BEDS OF NORTHERN BOLIVIA ${ }^{1}$
}

BRUCE J. MACFADDEN, KENNETH E. CAMPBELL, JR., RICHARD L. CIFELLI, OSCAR SILES, NOYE M. JOHNSON, CHARLES W. NAESER, AND PETER K. ZEITLER

Florida State Museum, University of Florida, Gainesville, FL 32611 (U.S.A.)

Natural History Museum of Los Angeles County, Los Angeles, CA 90007 (U.S.A.)

Division of Mammals, National Museum of National History,

Smithsonian Institution, Washington, D.C. 20560 (U.S.A)

Servicio Geológico de Bolivia, La Paz (Bolivia)

Department of Earth Sciences, Dartmouth College, Hanover, NH 03755 (U.S.A.)

Branch of Isotope Geology, U.S. Geological Survey, Denver, Colorado 80225 (U.S.A.)

Research School of Earth Sciences, Australian National University, Canberra, A.C.T. 2601 (Australia)

\section{ABSTRACT}

The Salla Beds contain a rich assemblage of Deseadan mammals that traditionally has been considered of early Oligocene age. These deposits, located 90-100 km SE of La Paz, Bolivia, consist of more than $540 \mathrm{~m}$ of principally fluviatile clays and silts with numerous interbedded tuffs. Paleomagnetic samples were collected from 104 sites spaced at stratigraphic intervals of about $6 \mathrm{~m}$. As a result of thermal demagnetization (at $400^{\circ} \mathrm{C}$ or greater), unambiguous polarities were determined for 76 of the 104 originally sampled sites. The pattern of reversals, stage of evolution of the fossils, and preliminary isotopic dates (including a K/Ar age of $26.4 \pm 1.0 \mathrm{Ma}$ and zircon fission track ages of ca. $22 \mathrm{Ma}$ ) from interbedded tuffs suggest that the Salla Beds correlate to chrons $\mathrm{C} 10$ through $\mathrm{C} 6$ of the magnetic polarity time scale, or an absolute time interval from about 28.5 to $24 \mathrm{Ma}$. Pyrotherium and caviomorph rodents occur throughout the section; the primate Branisella is known to occur at about $27 \mathrm{Ma}$. The Salla faunas seem to represent an earlier part of the Deseadan than faunas of this Land Mammal Age from Argentina. These data suggest that the early Deseadan should be shifted significantly upwards (by ca. $10 \mathrm{~m} . \mathrm{y}$.) to late Oligocene-early Miocene time.

\section{INTRODUCTION}

During most of the Cenozoic, South America drifted as an isolated continent, resulting in the evolution of a highly unique and endemic terrestrial fauna. In contrast to Holarctica, the fossil record of the Age of Mammals in South America is extensive but poorly known. Much of our knowledge of the South American succession comes from Argentina, Brazil, and some scattered critical

\footnotetext{
${ }^{1}$ Manuscript received October 22, 1984; revised January 29, 1985.

[Journal of Geology, 1985, vol. 93, p. 223-250] (C) 1985 by The University of Chicago. All rights reserved.

0022-1373/85/9303-/006\$1.00
}

sites in other countries. Although richly fossiliferous, the Tertiary sediments and faunas of Bolivia have been virtually unstudied until a recent surge of field activity within the last quarter century.

One of the most important Tertiary sites in South America is Salla, located in northwestern Bolivia. It has attracted considerable attention because it contains a very rich Deseadan assemblage, including the first occurrence of a South American primate (Branisella, Hoffstetter 1969; Wolff 1985) and a diverse suite of caviomorph rodents (Hoffstetter 1976; Hoffstetter and Lavocat 1970; Lavocat 1976; Patterson and Wood 1982). Other aspects of the Salla fauna have been published to date (see references below), but 
a detailed litho- and biostratigraphy and associated chronological framework of the Salla area has previously not been presented. Other Oligocene vertebrate faunules or isolated specimens have been reported from Bolivia (Lacayani, see Hoffstetter et al. 1971; Petaca Formation, see Sanjinés-S. and Jiménez-M. 1978), but the rich mammalian assemblage from Salla remains the standard for comparison with the classic Deseadan sequence of Argentina.

This report presents the results of an interdisciplinary analysis that suggests a new age for the sediments and faunas of the Salla Beds. In addition, this study integrates the preliminary mammalian biostratigraphy into a temporal scheme based on our collections and existing archival data associated with the more extensive Branisa collection housed at Princeton University. As more vertebrate fossil, paleomagnetic, and isotopic dating samples are collected and analyzed from Salla, and as knowledge of the sequence in Argentina increases, the present study will serve as a fundamental chronological foundation.

\section{ABBREVIATIONS}

The following abbreviations are used in the remainder of the text:

$\mathrm{AF}$; alternating field (demagnetization).

$\mathrm{A} / \mathrm{m}$; ampere/meter, equivalent to $10^{-3}$ Gauss.

$\mathrm{mT}$; millitesla, equivalent to 10 oersteds.

$\mathbf{R}$; resultant vector length, used in Fisher (1953) statistics.

NRM; natural remanent magnetization.

$k$; kappa, best estimate of precision parameter, used in Fisher (1953) statistics.

GB; paleontology collection, GEOBOL, La Paz, Bolivia.

GEOBOL; Servicio Geológico de Bolivia, La Paz, Bolivia.

MNHN SAL; Salla Collection, Museum National d'Histoire Naturelle, Paris, France.

UF/LACM/GB; collection from Salla made by joint expeditions of the University of Florida, Natural History Museum of Los Angeles County, and GEOBOL, presently housed at the Florida State Museum, University of Florida, Gainesville.

PU; vertebrate paleontology collection, Princeton University, Princeton, New Jersey.
$\mathrm{Ma}$; meg-annum, or million years before present on the radiometric time scale.

MPTS; Magnetic Polarity Time Scale

\section{PREVIOUS AND CURRENT INVESTIGATIONS}

Middle Tertiary vertebrates from Bolivia were completely unknown until the discovery of the Salla localities by G. Bejarano in 1962 (Hoffstetter 1968). Vertebrate fossils were collected from the Salla-Luribay basin during the mid 1960's for Princeton University by L. Branisa with funds provided by the Gordon Barbour bequest. During the late 1960s, and early 1970's, Hoffstetter of the Institut de Paleontologie, Paris, and associates made collections from Salla. Subsequent field work was also done there by Hartenberger of Montpellier, France, and Villarroel (formerly of GEOBOL, La Paz). The present paper has resulted principally from field collecting and geological investigations conducted at Salla since 1978, although portions are based on the PU collection.

Preliminary accounts of the geology of the Salla-Luribay basin have been presented by Hoffstetter (1968, 1976), Hoffstetter et al. (1971), and Villarroel and Marshall (1982). Hayashida et al. (1984) presented a study of fission track dating and magnetic stratigraphy of the Salla Beds. Our data indicate that their fission track (zircon) dates of $54.0 \pm 2.6 \mathrm{Ma}$ and 52.0 $\pm 2.1 \mathrm{Ma}$ are too old to indicate the true time of deposition of the Beds. Although several superposed magnetozones were detected by Hayashida et al. (1984), these were not correlated to the MPTS.

The majority of publications on Salla have been directed toward description of the rich vertebrate assemblage. Hoffstetter (1968) presented a preliminary faunal list of the Salla mammals. This fauna first attracted attention because of the presence of caviomorph rodents (references cited above), which are among the earliest-known in South America and the surprising discovery in the late 1960's of the ceboid monkey Branisella (Hoffstetter 1969; Wolff 1985). Recent papers have described numerous other aspects of the Salla fauna, including Argyrolagidae (Wolff 1984), Pyrotherium (MacFadden and Frailey 1984), marsupials (Villarroel and Marshall 1982; Patterson and Marshall 1978; Hoffstetter and Petter 1983; Petter and Hoffstetter 1983), litopterns (Cifelli and Soria 1983a, 1983b), 


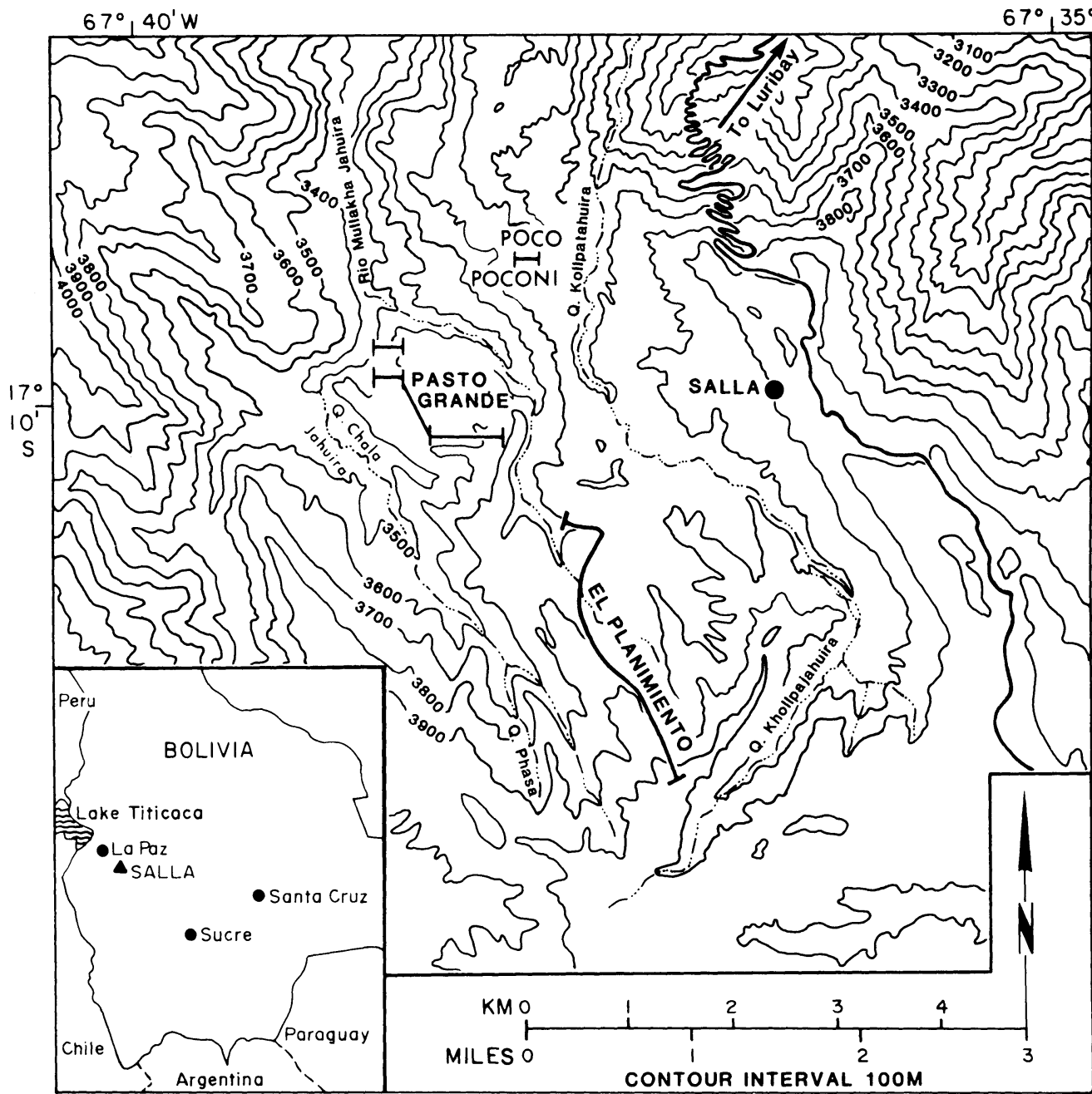

FIG. 1.-General location of the Salla-Luribay basin (insert, lower left corner) and detailed location of the three measured sections discussed in this report, i.e., Pasto Grande, Poco Poconi, and El Planimiento.

and a possible condylarth (Soria and Hoffstetter 1983). Despite the lack of precise field data for previous collections, some chronological constraints can be placed on many of those specimens based on our knowledge of general field areas (as contained in the archives at Princeton or published references).

\section{GEOGRAPHIC AND GEOLOGIC SETTING}

The Salla Beds are exposed in the SallaLuribay Basin, which is located about 90-100 $\mathrm{km} \mathrm{SE}$ of $\mathrm{La} \mathrm{Paz}$ in the Cordillera Orientale physiographic province at a general location of between lat. $17^{\circ} 8^{\prime}$ to $17^{\circ} 14^{\prime} \mathrm{S}$ and long. $67^{\circ} 40^{\prime}$ to $67^{\circ} 37^{\prime} \mathrm{W}$ at an elevation of about 3485 to $4085 \mathrm{~m}$ (fig. 1). The margins of the structural basin consist of deformed and locally metamorphosed Paleozoic sediments (Ahlfeld and Branisa 1960; Martinez and Tomasi 1978). The initial tectonic phases of basin development are represented by the Luribay Conglomerate, which lies unconformably on Paleozoic sediments. The age of this unit is early Tertiary; Hoffstetter (1976) stated that it was probably Eocene based on the anecdoctal occurrence of a notoungulate. The contact between the Luribay Conglomerates and overlying Salla Beds is gradational and best exposed in the NW portion of the basin along the south side of the Rio Mullakha Jahuira (fig. 2A). Several lines of evidence now indicate that the Salla Beds are 

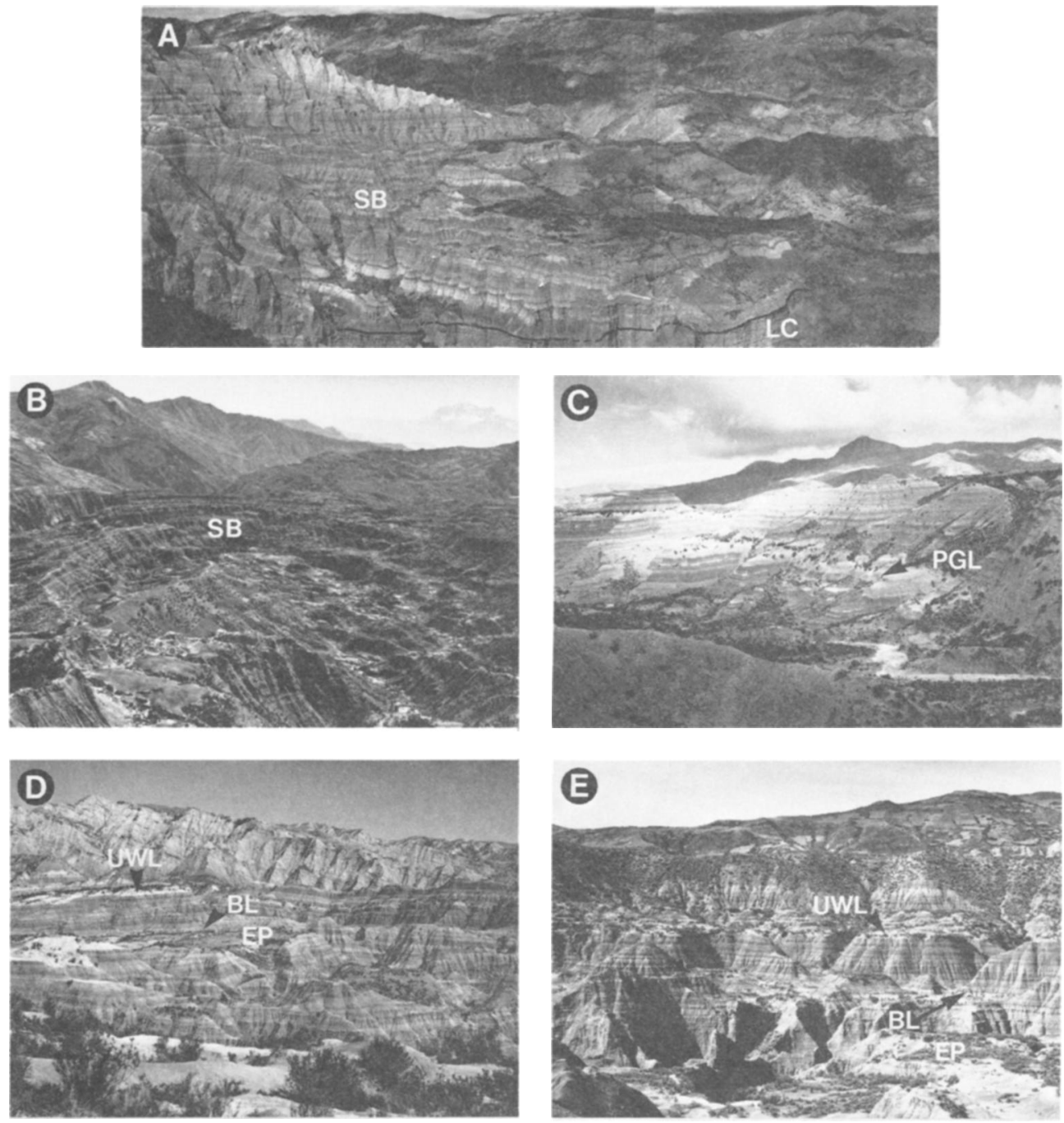

FIG. 2.-A. Lower part of the Salla section looking generally westward with the Rio Chala Jahuira in the middle distance. The approximate contact between the underlying Luribay Conglomerates and Salla Beds is indicated. Branisa's V-12 locality is in this general area. B. View of general structure of center of SallaLuribay basin looking $\mathrm{N}$ along the axis of the anticline formed by the Salla Beds. $C$. The Principal Guide Level (shown by arrow), a prominent lithostratigraphic marker in the Salla-Luribay basin taken NE of Poco Poconi and Khara Tranca Pata. D. The middle and upper part of the Salla Beds ("El Planimiento" section, see below) exposed near the axis of the principal anticline. The lower part of this section, including the Branisella and Upper White levels, are among the most highly fossiliferous portions of the Salla Beds. $E$. The middle part of the Salla Beds with the Branisella and Upper White levels looking east (in the general direction of the village of Salla). The arrow labelled BL to the right (south) of our Campsite II indicates the exact locality of the Branisella partial maxilla, UF 27887, collected by one of us (B. J. MacF.) in 1981. In figures $2 D$ and $2 E$, the grass and low shrub covered surface just below the Branisella level is "El Planimiento." Abbreviations are as follows: LC, Luribay Conglomerates; PGL, Principal Guide Level; SB, Salla Beds; UWL, Upper White Level; BL, Branisella Level; EP, El Planimiento.

late Oligocene to early Miocene in age, which is a significant departure from previous interpretations. Post-depositional deformation resulted in the folding and faulting of these Tertiary sediments into a broad anticline with an axis trending NNW-SSE (fig. 2B). Locally, the Salla Beds are covered by a thin (usually less than $10 \mathrm{~m}$ ) unit of unnamed fine-grained alluvial or aeolian deposits which are probably of Pleistocene age. 
The Salla Beds consist of at least $540 \mathrm{~m}$ of section exposed in the core of the anticline. The predominant lithology consists of moderately to well-indurated red-brown, pinkishtan, and light gray claystones and siltstones. Locally, these colors can be either massive or variegated in outcrop. There are numerous tuffaceous horizons which represent either primary air-falls or secondarily reworked deposits. A prominent lithostratigraphic marker, the "Principal Guide Level" (Nivel Guia in Villarroel and Marshall 1982) is used for correlation within the Salla-Luribay basin (fig. 2C). Infrequently, the Salla Beds contain local lenticular channel conglomerates and thin (ca. $1 \mathrm{~m}$ ) limestones. These lithologies suggest that the Salla Beds were deposited principally in a fluviatile environment. The variegated horizons probably represent paleosols.

The Salla Beds weather to a characteristic badlands topography. Fossil vertebrates are relatively rare in the lower and upper onethird of our composite section. The principal fossiliferous horizons are located in the middle one-third of the Salla Beds (figs. $2 D$ and $2 E$ ). The fossils are usually isolated, oftentimes occurring as fragmentary dentitions and postcranial elements dispersed randomly within these zones. Infrequently, articulated specimens have been found. Our field work suggests that there are few, if any, horizons amenable to quarry sampling. Therefore, our Salla collections made thus far are the results of surface prospecting.

\section{PALEOMAGNETIC PROCEDURES AND ANALYSES}

In 1981 paleomagnetic samples were collected from three measured stratigraphic sections in the Salla Beds (fig. 1). These sections were chosen because: (1) they collectively span what seems to represent the most complete composite sequence available; (2) they are relatively continuous and consist of sediments potentially amenable to paleomagnetic sampling; (3) they include important fossiliferous, marker, and ash horizons; and (4) they are located in the undeformed portion of the basin. A total of 104 paleomagnetic sites were collected from the three sections which total a composite thickness of $540 \mathrm{~m}$. A minimum of three separately-oriented hand samples were taken at each site. The vertical separation between sites averages about $6 \mathrm{~m}$, and in no case does the separation between two superposed sites exceed $10 \mathrm{~m}$.

In the laboratory the paleomagnetic samples were cut and sanded into $25 \mathrm{~mm}$ cubes. All paleomagnetic measurements, laboratory treatment, and data analyses were conducted at the University of Florida Paleomagnetic Laboratory. This study employed a Superconducting Technology two-axis cryogenic magnetometer (Goree and Fuller 1976) on which most of the measurements of magnetization were made; a Schonstedt DSM-2 spinner magnetometer, Schonstedt alternating field (AF) and thermal demagnetizers and Apple II series microcomputers for data collection and analyses.

In order to determine the paleomagnetic characteristics for the sediments of the Salla Beds, 18 sites selected from varied lithologies were used for a pilot demagnetization study. For eight of these sites, one specimen was subjected to step-wise AF demagnetization (at NRM, 10, 20, 30, 40, 50, and $60 \mathrm{mT}$ ), and one specimen was subjected to step-wise thermal demagnetization (at NRM, 100, 200, $300,400,500,550,600,620$, and $640^{\circ} \mathrm{C}$ ). The additional 10 sites were subjected to the complete step-wise thermal demagnetization regime. The results of the step-wise AF pilot demagnetization indicate that in many cases, a high coercivity magnetic component was present that could not effectively be removed by this technique (fig. $3 A, 3 B, 3 D$ ). AF demagnetization effectively isolated a stable component in only one of the eight pilot specimens as evidenced by a general linear decay towards the origin in vector demagnetization (Zijderveld) diagrams (fig. $3 C$ ). The results of the step-wise thermal demagnetization (fig. 4) indicate that, in general, after a low blocking temperature component is removed at temperatures of about $100-200^{\circ} \mathrm{C}$, a stable magnetic component seems to be isolated between $300^{\circ}$ and $550^{\circ} \mathrm{C}$. Above $550^{\circ} \mathrm{C}$ the magnetic component usually continues to decay in the same direction as between $300^{\circ}-550^{\circ} \mathrm{C}$ (fig. $4 A, 4 C$, and $4 D$ ) or sometimes becomes unstable with no linear decay towards the origin (fig. 4B). NRM intensities of magnetization usually fall in the $10^{-7}$ and $10^{-8} \mathrm{~A} / \mathrm{m}$ range. After thermal demagnetization at $400^{\circ} \mathrm{C}$, and for some specimens (see above) at $500^{\circ} \mathrm{C}$, intensities of 


\section{AF DEMAGNETIZATION}

A

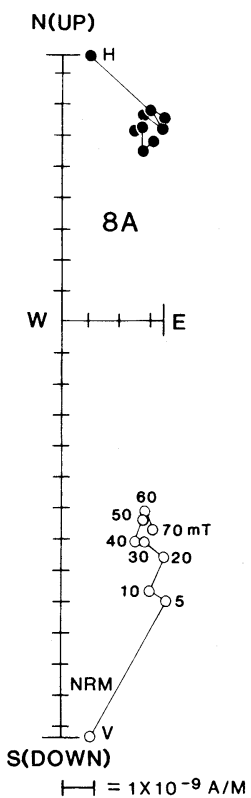

B

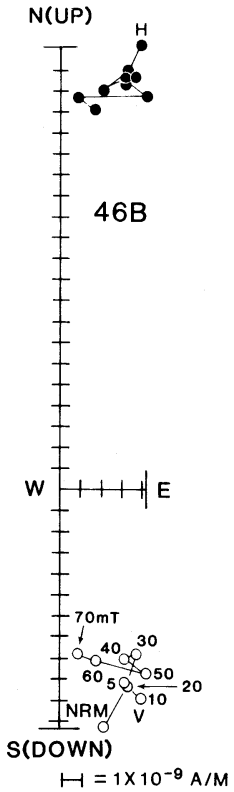

C

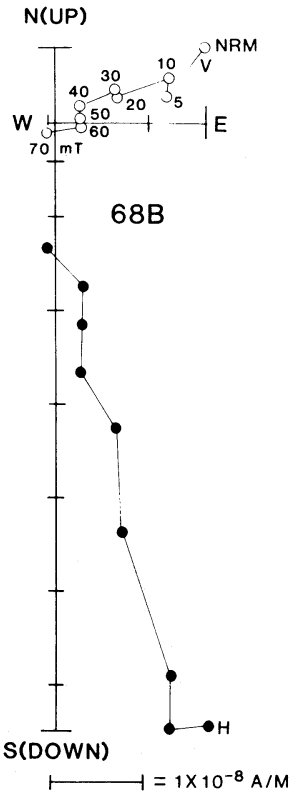

D

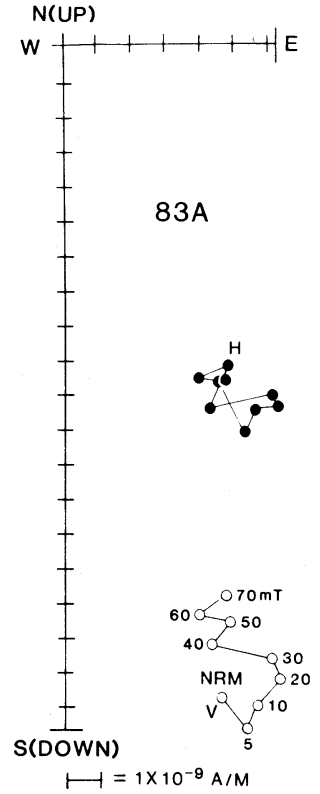

FIG. 3.-AF demagnetization characteristics for four representative samples from the Salla Beds, $8 \mathrm{~A}(A)$, 46B $(B), 68 \mathrm{~B}(C)$, and 83A $(D)$. Closed and open squares represent, respectively, horizontal and vertical components on these vector demagnetization (Zijderveld) diagrams.

THERMAL DEMAGNETIZATION

A

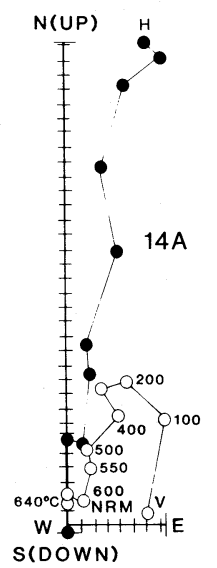

$H=1 \times 10^{-7} \mathrm{~A} / \mathrm{M}$
B

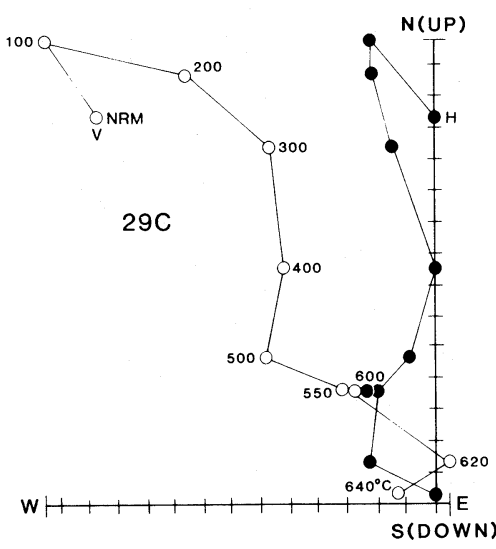

$\longmapsto=1 \times 10^{-8} \mathrm{~A} / \mathrm{M}$

\section{C} ${ }_{300 \mathrm{C}^{2}}^{\mathrm{V}}{ }^{1000}$

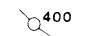

$0^{500}$

49C

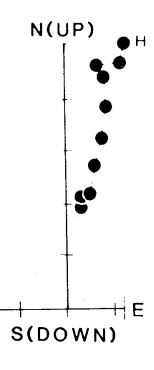

D

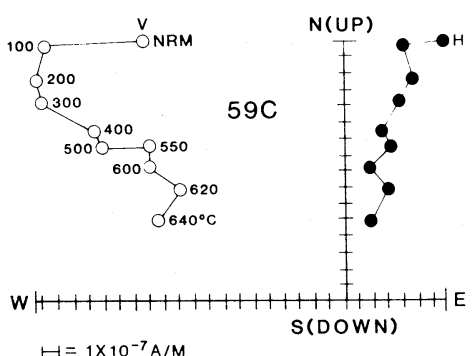

FIG. 4.-Thermal demagnetization characteristics for four representative samples from the Salla Beds, 14A $(A), 29 \mathrm{C}(B), 49 \mathrm{C}(C)$, and $59 \mathrm{C}(D)$. Conventions for these vector demagnetization diagrams are the same as in figure 3. 


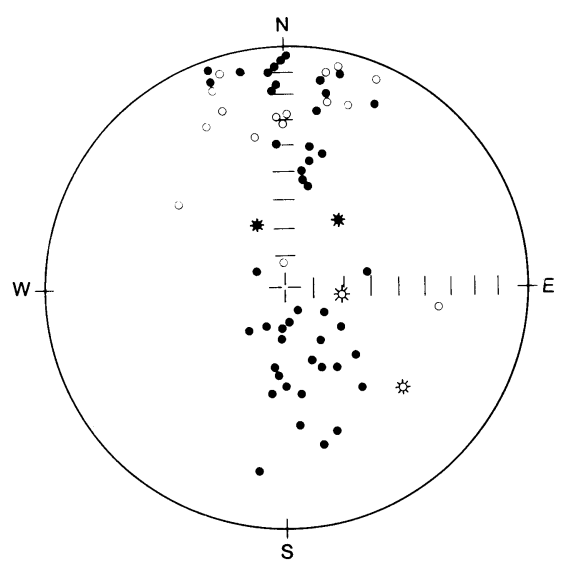

B. OPTIMUM THERMAL DEMAGNETIZATION

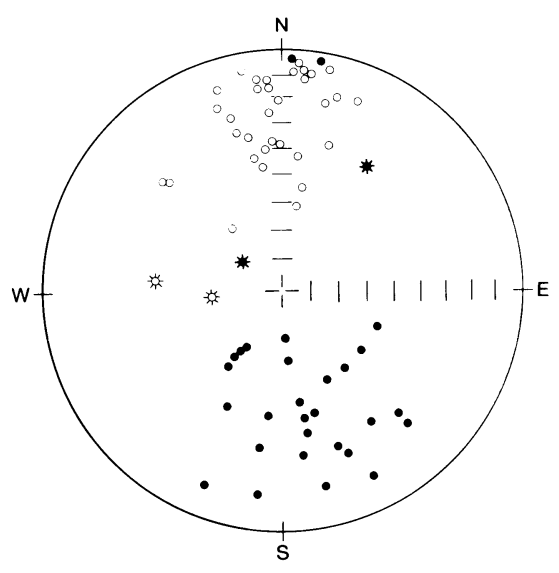

FIG. 5.-Stereographic projections of the statistically significant site mean directions for the Salla Beds. $A$. NRM. B. After "optimum" thermal demagnetization (the data set with greater precision, see text). Closed and open circles represent, respectively, sites of positive and negative inclinations. After demagnetization, the population of sites in the northern hemisphere with negative inclinations and those in the southern hemisphere with positive inclinations are interpreted to be of, respectively, normal and reversed polarity. The four sites represented by asterisks are statistically significant but of dubious polarity.

magnetization usually fall in the $10^{-8}$ and $10^{-9} \mathrm{~A} / \mathrm{m}$ range.

After thermal demagnetization and data analysis using Fisher (1953) statistics, of the 104 sites sampled, 76 were used to interpret the magnetic polarity zonation presented below. Following the criteria of Opdyke et al. (1977), 63 fell into the Class I category (statistically significant), one into Class II (only two samples analyzed from the site), and 12 into Class III (two of three samples with concordant directions).

The directional data for the Class I sites for NRM and "optimum" demagnetization are presented in figure 5. For sites demagnetized at two steps, i.e., $400^{\circ} \mathrm{C}$ and $500^{\circ} \mathrm{C}$, the data were chosen (as "optimal") with the higher precision $(k)$. Sites were rejected from the Class I category if they did not meet the reliability criteria set forth in Irving (1964, p. 68) where for $\mathrm{N}=3 ; \mathrm{R}>2.62$ and $\mathrm{N}=4 ; \mathrm{R}>$ 3.10. For the NRM site mean data, there is considerable scatter of directions with sites of both positive and negative inclinations, particularly in the northern hemisphere (fig. $5 A$ ). After thermal demagnetization, the sites tend to separate into two populations, one in the northern hemisphere with negative inclinations (interpreted to be of normal polarity) and one in the southern hemisphere with positive inclinations (interpreted to be of re- versed polarity). The separation into two populations suggests that in most cases, the thermal demagnetization regime used here satisfactorily isolated the characteristic component of magnetization. However, sites of intermediate distribution between the two populations suggest that our thermal demagnetization did not remove completely all secondary components of the NRM. In addition, four Class I sites, although statistically significant, were of ambiguous polarity (declinations in northern hemisphere with positive inclinations or declinations in southern hemisphere with negative inclinations). These sites were not used to interpret the magnetic polarity zonation presented below.

The mean directional data for the 42 Class I demagnetized sites of normal polarity is declination $357.21^{\circ}$, inclination $-24.89^{\circ}(\mathrm{R}=$ $\left.39.24, k=14.87, \alpha_{95}=5.92^{\circ}\right)$. The mean directional data for the 30 Class I demagnetized sites of reversed polarity is declination $169.45^{\circ}$, inclination $45.02^{\circ}(\mathrm{R}=27.25, k$ $\left.=10.55, \alpha_{95}=8.5^{\circ}\right)$. These two populations do not pass a "reversals test" at the $95 \%$ confidence level (McElhinny 1973). The reversed and normal populations are significantly different from each other and from the dipolar field $\left(31.44^{\circ}\right)$ calculated for the latitude of Salla $\left(17^{\circ} \mathrm{S}\right)$ (using the formula tan $\mathrm{I}=2 \tan \lambda$, where $\lambda=$ known present-day 


\section{PASTO GRANDE}

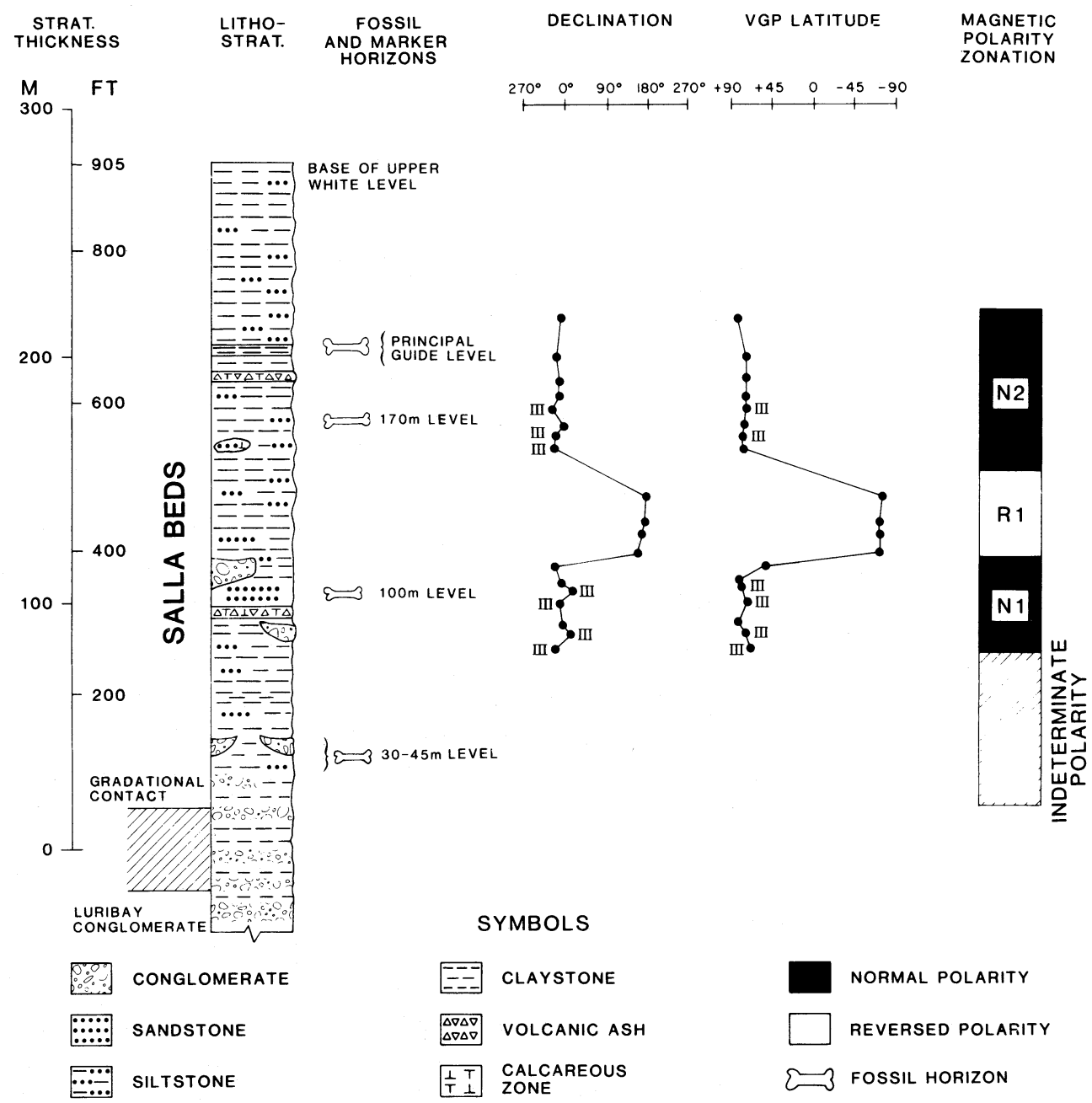

FIG. 6.-Lithostratigraphy, important horizons, and magnetostratigraphic data for the Pasto Grande section. All paleomagnetic sites are Class I unless otherwise indicated (i.e., II or III).

latitude and $\mathrm{I}=$ predicted inclination). These divergences from expected inclinations probably result from incomplete removal of secondary components of magnetization. Nevertheless, as mentioned above, the polarities are unambiguously determined for 76 of the 104 originally sampled sites.

\section{LITHOSTRATIGRAPHY AND MAGNETIC POLARITY STRATIGRAPHY}

The locations of the three measured stratigraphic sections, Pasto Grande, Poco Poconi, and El Planimiento are shown in figure 1. Together, they comprise $540 \mathrm{~m}$ of composite section and include known important fossil, marker, and tuffaceous horizons.

Pasto Grande.-This section (fig. 6), located at lat. $17^{\circ} 9^{\prime} 45^{\prime \prime} \mathrm{S}$, long. $67^{\circ} 38^{\prime} 30^{\prime \prime} \mathrm{W}$ (fig. 1), consists of about $265 \mathrm{~m}$ of the Salla Beds representing about the lower one-third of the known stratigraphic extent of this unit. The lower contact with the underlying Luribay Conglomerates is gradational (fig. $2 A$ ). Locally, the Salla Beds have dips of $10^{\circ}$ $\mathrm{N}$ or less, and they consist principally of moderately indurated reddish brown silty claystones and clay siltstones. Other smaller units consist of poorly indurated gray sands, 
POCO POCONI
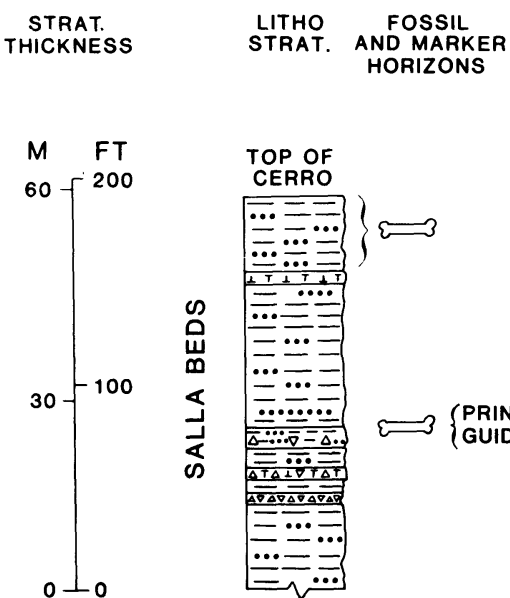

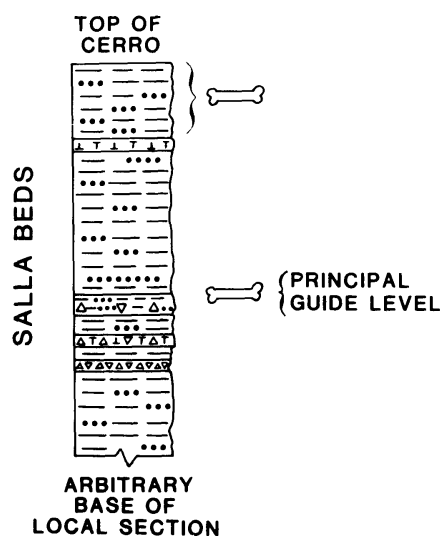

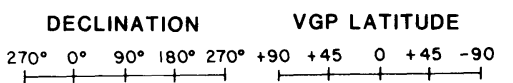

MAGNETIC POLARITY ZONATION
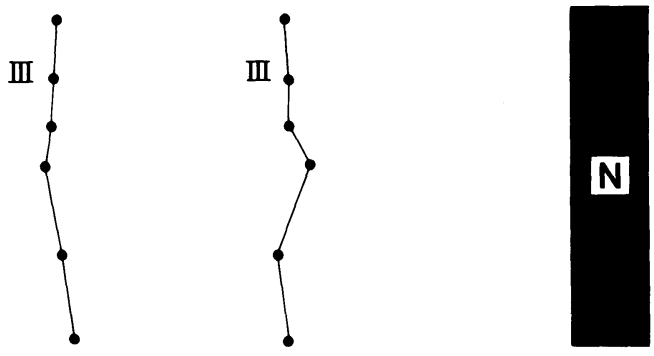

FIG. 7.-Lithostratigraphy, important horizons, and magnetostratigraphic data for the Poco Poconi section. See figure 6 for symbols and conventions.

lenticular conglomerates, and several thin (1 $\mathrm{m})$ tuffaceous horizons. At 205-210 m there is a prominent white band of silty, bentonitic claystone that weathers to a characteristic "popcorn" surface. This unit, the "Principal Guide Level," is one of the most prominent lithostratigraphic marker horizons in the Salla-Luribay basin (fig. 2C). The top of the Pasto Grande section was arbitrarily placed at the base of another prominent stratigraphic marker, the "Upper White Level."

Although not as rich nor as intensively prospected as certain other areas in the Salla Beds, fossil vertebrates have been collected from several horizons in the Pasto Grande section. These levels occur at $35-40 \mathrm{~m}, 100$ $\mathrm{m}, 170 \mathrm{~m}$, and 205-210 $\mathrm{m}$ (Principal Guide Level) above the base of the section (fig. 6). In addition, Branisa's notes and correspondence (on file in the Department of Geology, Princeton University) indicate that certain of his localities (V-12, Anchallani, and Quebrada Chala Jahuira) occur within the lower one-third of the Salla Beds either at Pasto Grande or from stratigraphically equivalent sections. In particular, the correlative section at Quebrada Chala Jahuira (figs.1, 2A) is important because it records the lowest stratigraphic level of rodents in the Salla Beds.

Three magnetozones ( $2 \mathrm{~N}$ and $1 \mathrm{R})$ are represented by 21 sites in the Pasto Grande sec- tion (fig. 6). Twelve paleomagnetic sites were originally collected from the lowermost $77 \mathrm{~m}$ of the Salla Beds. However, because of numerous single site polarity zones in that part of the section, this portion of the magnetic polarity zonation is considered here to be indeterminate (more sampling is required to extend the paleomagnetic column further down the section).

Poco Poconi.-This section (fig. 7), located at lat. $17^{\circ} 10^{\prime} 15^{\prime \prime} \mathrm{S}$, long. $67^{\circ} 38^{\prime} \mathrm{W}$ (fig. 1), consists of $60 \mathrm{~m}$ of the Salla Beds. This section was chosen because it includes important fossil localities. Its base was arbitrarily started $25 \mathrm{~m}$ below the Principal Guide Level. In this section the dips are less than $10^{\circ}$. The sediments of the Salla Beds at Poco Poconi consist predominantly of moderately indurated reddish-brown silty claystones and clayey siltstones with some interbedded light gray well-indurated calcareous fine sandstones and tuffaceous poorly indurated sands. The prominent marker horizon, the Principal Guide Level, is present in this section.

Two fossil horizons occur in the Poco Poconi section. The lower one is at the Principal Guide Level. The main concentration, named the Branisella Level (see below), occurs in the upper one-quarter of the section above a gray-brown, well indurated, ledge-forming, 


\section{EL PLANIMIENTO}

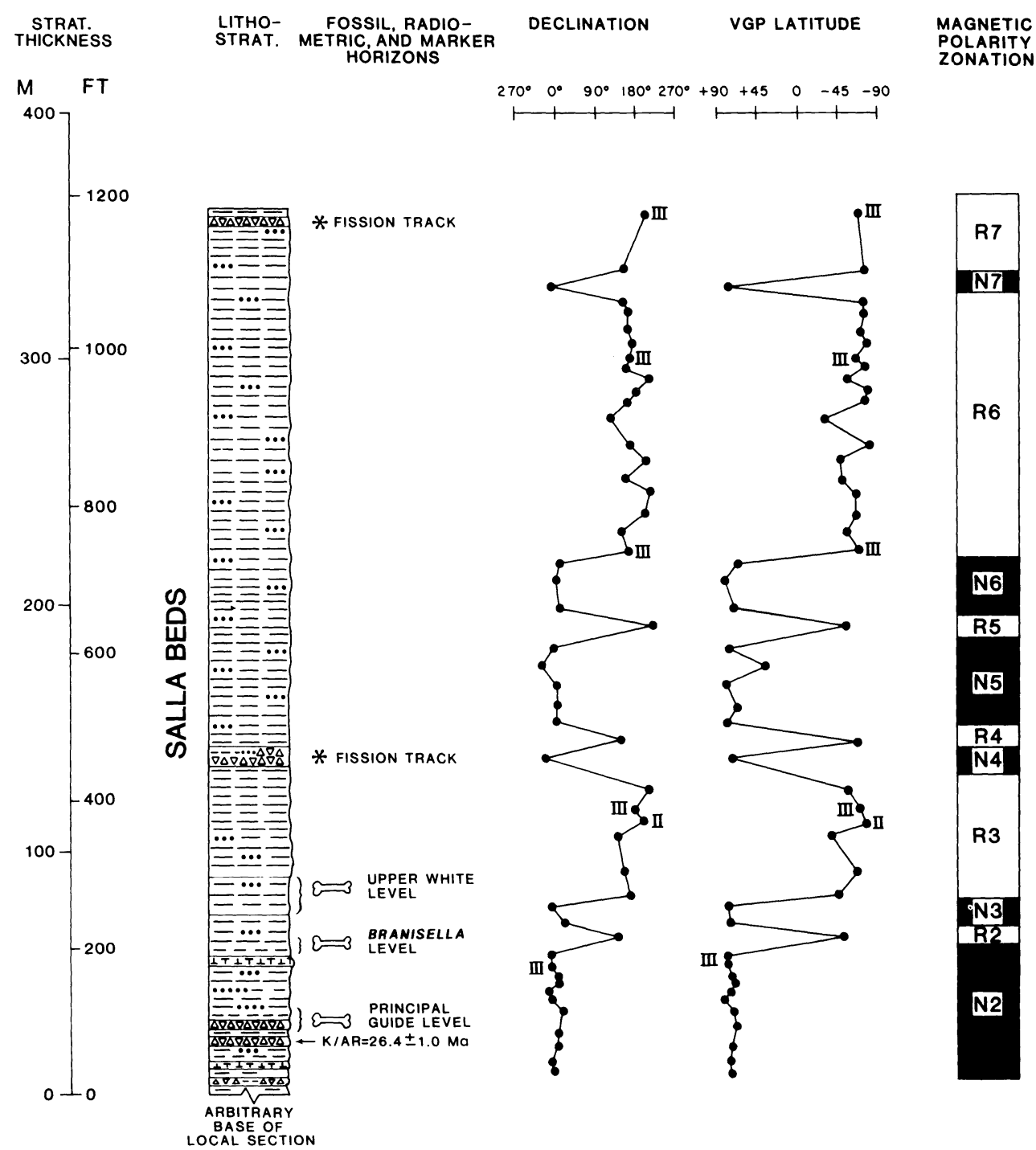

FIG. 8.-Lithostratigraphy, important horizons, and magnetostratigraphic data for the El Planimiento section. See figure 6 for symbols and conventions. The levels of the fission track dates are indicated; however, these were not used in our present chronology for the reasons discussed in the text.

$0.3 \mathrm{~m}$ thick calcareous sandstone located at $50 \mathrm{~m}$ above the local stratigraphic base. Based on seven superposed sites, this entire section consists of one zone of normal polarity.

Recently, a highly fossiliferous new horizon, Calabozo Pata, located $45 \mathrm{~m}$ below the base of the Principal Guide Level (below our previously measured section), was worked in the region of Poco Poconi and Khara Tranca Pata (figs. 1, 2C). Calabozo Pata is biostratigraphically very important because it seems close to the lowest stratigraphic level at which rodents are abundant.

El Planimiento.-This section (fig. 8), located between lat. $17^{\circ} 11^{\prime}$ and $17^{\circ} 12^{\prime} \mathrm{S}$, long. $67^{\circ} 37^{\prime} 30^{\prime \prime} \mathrm{W}$, consists of about $365 \mathrm{~m}$ of the Salla Beds. It was chosen because it represents a long portion of the upper part of the Salla Beds that includes important marker and ash horizons, and because the most abundant and diverse suite of mammals known from the basin are found there. The base of this section was arbitrarily taken $25 \mathrm{~m}$ 
TABLE 1

K/Ar Analytical Data for Unit 5 Biotite

\begin{tabular}{lcccc}
\hline \hline $\begin{array}{l}\text { ANU } \\
\text { lab no. }\end{array}$ & $\begin{array}{c}\mathrm{K}^{\mathrm{a}} \\
(\text { wt \%) }\end{array}$ & $\begin{array}{c}\text { Radiogenic }{ }^{40} \mathrm{Ar} \\
\left(10^{-10} \mathrm{~mol} / \mathrm{g}\right)\end{array}$ & $\begin{array}{c}\text { Radiogenic }{ }^{40} \mathrm{Ar} \\
(\% \text { of total })\end{array}$ & $\begin{array}{c}\text { Age } \\
(\mathrm{Ma} \pm 1 \sigma)\end{array}$ \\
\hline $84-4(1)^{\mathrm{b}}$ & $6.343,6.385$ & 2.900 & 69.0 & $26.1 \pm 0.4$ \\
$84-4(2)^{\mathrm{c}}$ & $6.343,6.385$ & 2.972 & 92.3 & $26.7 \pm 0.3$ \\
\end{tabular}

NotE.-Unit 5 biotite is located $20 \mathrm{~m}$ above the local base of the El Planimiento section and $195 \mathrm{~m}$ above the base of the composite section of the Salla Beds.

$\lambda_{\mathrm{e}}+\lambda_{\mathrm{e}^{\prime}}=0.581 \times 10^{-10} \mathrm{yr}^{-1} ; \lambda_{\beta}=4.962 \times 10^{-10} \mathrm{yr}^{-1} ;{ }^{40} \mathrm{~K} / \mathrm{K}=1.167 \times 10^{-4} \mathrm{~mol} / \mathrm{mol}$.

${ }^{\mathrm{a}} \mathrm{K}$ measured by flame photometry. As measured by isotope dilution using a VG Isotopes MM1200 mass spectrometer operated in static mode.

$+152 \mu \mathrm{m} ; 0.09758 \mathrm{~g}$

$+152 \mu \mathrm{m} ; 0.16269 \mathrm{~g}$.

below the Principal Guide Level. This section was measured along the axis of the general anticlinal structure of the basin (fig. 2B), where the sediments are flat-lying. The principal lithology in the lower half of the Salla Beds in this section is reddish brown, moderately indurated silty claystones and clay siltstones. In the upper half of this local section, there is a distinct color change to pale brown and pinkish tan although the predominant grain sizes are the same as in the lower half. Throughout there are numerous interbedded light colored well-indurated calcareous sandstones (two of which, between 195$200 \mathrm{~m}$, form the resistant base of "El Planimiento," fig. $2 D$ and $2 E$ ), claystones, tuffs, and tuffaceous silty clays.

Our Upper White Level, at about $83 \mathrm{~m}$ above the local base, is a prominent lithostratigraphic marker in the central part of the Salla basin (fig. 2). It consists of white, dark gray, and red bentonitic clays that weather to a characteristic "popcorn" surface. Our section ends at the top of an unnamed ridge crest at an elevation of $4078 \mathrm{~m}$.

Very rich fossil horizons occur in the lower one-third of this section. As shown in figures $2 D, 2 E$, and 8 , these include the Principal Guide Level at 25-30 m, our "Branisella Level" [Tapial Pampa of Branisa (correspondence at PU) and Villarroel and Marshall 1982] and our Upper White Level (Cebadal Churu, Huichinca and equivalents of Villarroel and Marshall 1982). The upper twothirds of this local section is not highly fossiliferous, although some unidentifiable bone scraps have been encountered during field work.

Comments on Single-Site Polarity Zones. -Based on 51 paleomagnetic sites, 12 mag- netozones $(6 \mathrm{~N}, 6 \mathrm{R})$ are represented in the $\mathrm{El}$ Planimiento section. Five of these zones ( $2 \mathrm{~N}$ and 3R), i.e., R2, N4, R4, R5, and N7, are based on Class I single sites. Because of the possibility that these sites could represent spurious magnetic polarities, further laboratory analysis was performed for all samples from each site. All samples were measured for NRM, demagnetized at $400^{\circ} \mathrm{C}$ and $500^{\circ} \mathrm{C}$ (as was the routine procedure described above), and then were also demagnetized at $550^{\circ} \mathrm{C}, 600^{\circ} \mathrm{C}, 620^{\circ} \mathrm{C}$, and $640^{\circ} \mathrm{C}$. In all cases, these sites remained of the same polarity as determined from demagnetization at lower temperatures.

Given the results of this additional laboratory analysis and using the criteria described above for acceptance/rejection of sites (Opdyke et al. 1977), a non-arbitrary scheme does not exist for rejecting these five sites in an interpretation of the magnetic polarity zonation. These single site polarity zones are thus considered to be short-term reversals. Problems have been encountered in previous studies with the use of single site polarity zones in correlation. Therefore, only polarity transitions between zones represented by two or more sites are used below. In this way, the short-term (i.e., single site) polarity zones do not affect our correlation of the Salla magnetic polarity zonation to the standard MPTS.

\section{ISOTOPIC DATING}

The Salla Beds contain numerous volcanic tuffs and bentonized tuffs that are amenable to isotopic dating. We report one $\mathrm{K} / \mathrm{Ar}$ date on biotite (table 1) and two fission-track dates on zircons (table 2). The analytical data for these ages are internally consistent. They 


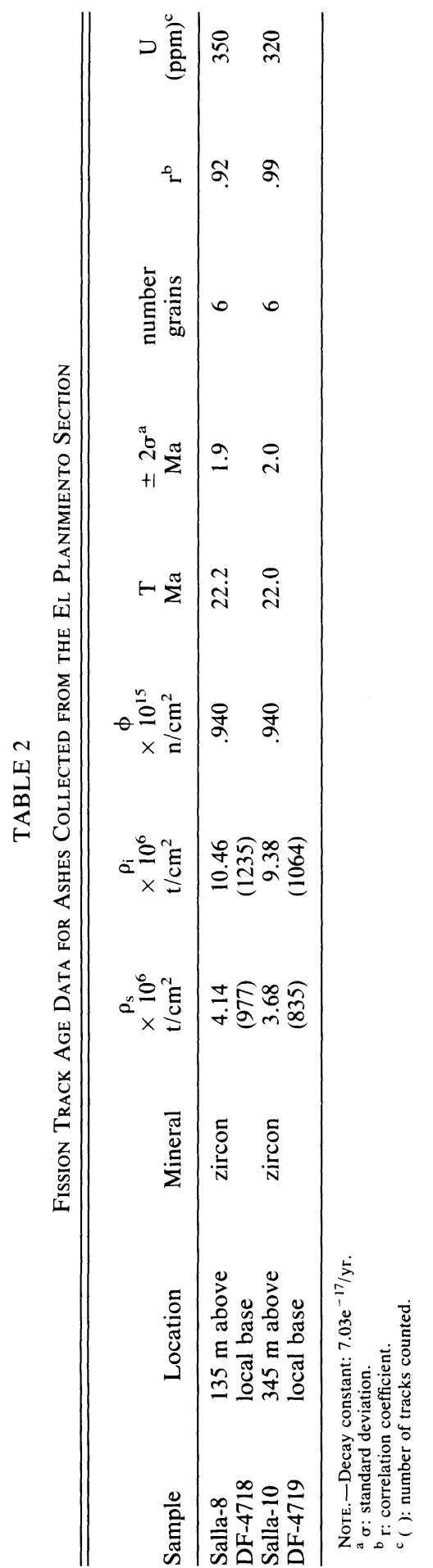

therefore seem to approximate closely the real ages of the associated air-fall events.

The $\mathrm{K} / \mathrm{Ar}$ date was obtained from air-fall biotites found at the $20 \mathrm{~m}$ level above the local base in the El Planimiento section (fig. 8). Two splits were dated with good reproducibility (table 1). The mean age for these is $26.4 \pm 1.0(2 \sigma) \mathrm{Ma}$. These analyses were performed at the isotope geology laboratory at the Australian National University.

The two fission-track determinations on zircon were obtained from tuffaceous units at the $135 \mathrm{~m}$ and $355 \mathrm{~m}$ levels above the local base in the El Planimiento section (fig. 8). The analytic data for these dates, obtained with the external detector method (Naeser 1979), are presented in table 2 . The zircon grains were mounted in FEP teflon at $300^{\circ} \mathrm{C}$. The grain mount was then polished, and the fossil tracks etched. The zircons were etched for 34 hours in a eutectic melt of $\mathrm{KOH}$ and $\mathrm{NaOH}$ at $215^{\circ} \mathrm{C}$ to develop the tracks (Gleadow et al. 1976) and then were covered with an external detector of muscovite to record the induced fission tracks. This package was then irradiated with NBS glass standard 962 in the USGS Reactor at Denver, Colorado. Following irradiation, the muscovite detector was etched in $48 \% \mathrm{HF}$ at $20^{\circ} \mathrm{C}$ for 15 minutes. The neutron dose was determined by counting the number of tracks in a muscovite detector which covered the glass standard during the irradiation. The NBS Cu calibration was used in determining the dose. The error reported in table 2 was determined by using Poisson statistics based on the total number of tracks counted.

Discussion.-The analysis for both the K/ $\mathrm{Ar}$ and fission-track dates indicates precise ages; however, the dates derived from these two techniques are not mutually compatible with the chronology presented here. The fission-track ages from Salla sample 8 and Salla sample 10 (table 2), which are separated (in direct superpositional sequence) by $210 \mathrm{~m}$ of section, essentially yield equivalent ages of ca. $22 \mathrm{Ma}$. Given the fact that seven polarity transitions separate these two dates, and using the stochastic model of geomagnetic field reversals (Johnson and McGee 1983), it is clear that a significantly greater period of time is actually represented between these two tuffs (more sampling and analysis is required to provide temporal discrimination be- 
tween these sites). We view the fission-track dates as general corroboration of the $\mathrm{K} / \mathrm{Ar}$ age, the latter of which we chose to accept for calibration of our magnetic polarity zonation and correlation to the MPTS.

In summary, both of these isotopic techniques indicate that the middle to upper part of the Salla Beds, and their Deseadan fossils, are in the mid to low 20's Ma age range. This is substantially younger than previously stated for Deseadan fossils, i.e., ca. 33-35 Ma (Marshall et al. 1983). It is improbable that both of our isotopic methods have systematic errors of this magnitude. Nevertheless, we are presently resampling and redating these and other tuffs to validate further the $\mathrm{K} / \mathrm{Ar}$ date used here for calibration of the magnetic polarity zonation.

\section{MAMMALIAN FAUNA}

The UF/LACM/GB and PU collections were studied to determine the composition and stratigraphic distribution of the mammals collected from the Salla Beds. With respect to the UF/LACM/GB collection, fossil levels are located throughout the composite section as follows (fig. 9): (1) the lowermost at 30-45 $\mathrm{m}$ above the base; (2) the $100 \mathrm{~m}$ level; (3) the $160 \mathrm{~m}$ level (Calabozo Pata); (4) $170 \mathrm{~m}$ level; (5) Principal Guide Level at 205-210 m; (6) 230-240 m level, which is equivalent to the Branisella Level ( = Tapial Pampa sensu stricto, see Villarroel and Marshall 1982); and (7) 260-270 m level or Upper White Level ( = Branisa's white-gray gypsiferous clay; = Huichinca of Villarroel and Marshall 1982). In the PU Bransia collection many specimen localities are cited merely as within the general Salla area. However, correspondence between Branisa and Dr. G. L. Jepsen (late Professor of Geology at Princeton), associated photographs, and our knowledge of the general field relations indicate that several of Branisa's more specific localities can be placed in our stratigraphic scheme (fig. 9): (1) V-12 ( = Quebrada Chala Jahuira = Anchallani) is located above the Luribay Conglomerates in sediments equivalent to the lower part of the section, and it possibly extends stratigraphically as high as, although almost certainly not above, the Principal Guide Level. (2) V-2 and V-3 are located above the Principal Guide Level. Most of the fossils collected from these "localities" are proba- bly in the extremely fossiliferous zone between the Principal Guide Level through the Upper White Level. It is not possible to determine how far above the Upper White Level Branisa's collection extends; however, based on the fact that the upper one-third of the Salla Beds is poorly fossiliferous, there probably are not many specimens from this part of the section. Given these constraints, the preliminary biostratigraphy (fig. 9) is divided into two informal parts, the lower and upper Salla Beds, with the transition between these taken arbitrarily at the Principal Guide Level (fig. 10).

The stratigraphic distribution of fossil mammals at Salla is presented in figure 10 . Hoffstetter $(1968,1976)$ presented a preliminary, annotated faunal list for the mammals from Salla. Since that time many groups have been described from that fauna, i.e., primates (Hoffstetter 1969; Wolff 1985) marsupials (Villarroel and Marshall 1982; Patterson and Marshall 1978; Hoffstetter and Petter 1983; Petter and Hoffstetter 1983); litopterns (Cifelli and Soria 1983a, 1983b) and a possible condylarth (Soria and Hoffstetter 1983). The taxonomy of many of the Salla mammals has recently been studied, so that their biostratigraphic utility is fairly good. Other groups from Salla, particularly the edentates and notoungulates, are virtually unstudied. The following list (also see table 3 ) includes preliminary identifications based on comparisons with Deseadan mammals from Argentina mostly resulting from the unpublished work of one of us (R.L.C.).

MARSUPIALIA:

Paraborhyaena boliviana.-Hoffstetter and Petter (1983) and Petter and Hoffstetter (1983) describe this large borhyaenid from Salla (also see description of Proborhyaena gigantea in Patterson and Marshall 1978). This same taxon recently was reported as Proborhyaena gigantea from Argentina (Bond and Pascual 1983, Marshall pers. comm.). The hypodigm from Salla is small, consisting of four specimens (two in MNHN and two in the PU collection, see Petter and Hoffstetter 1983). None of the MNHN or PU specimens have specific locality data so that this species is listed as occurring from the general "Salla" area in figure 10.

Pharsophorus lacerans.-Patterson and 

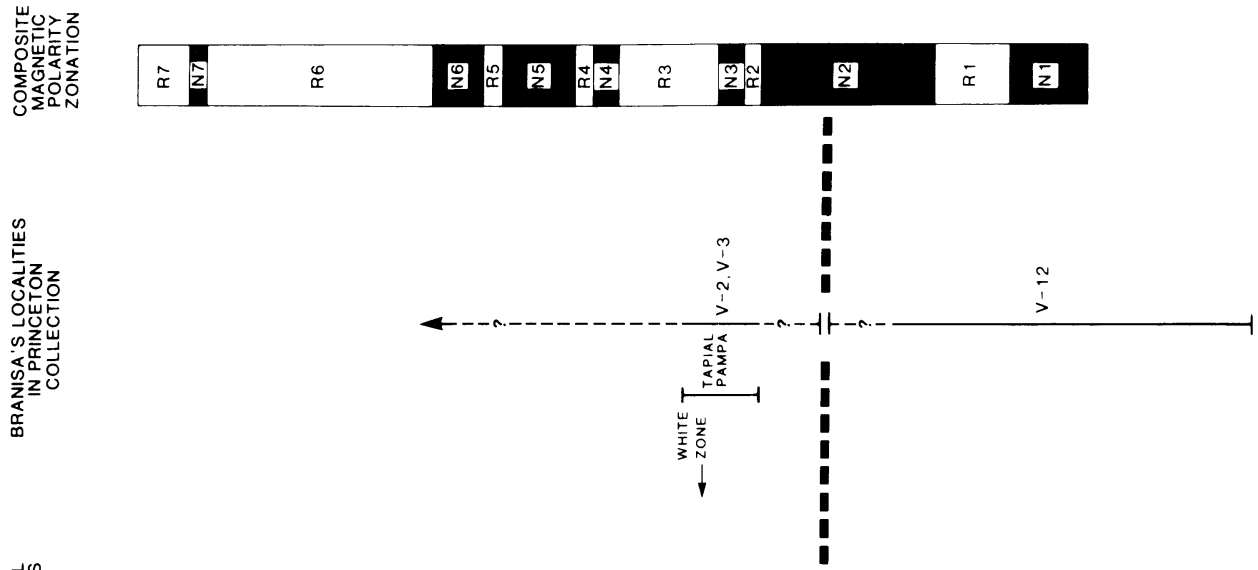

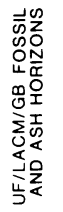

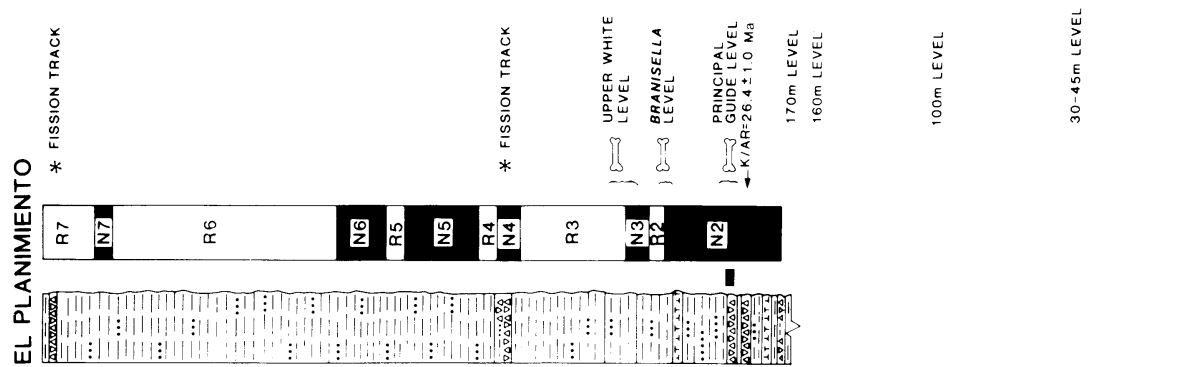

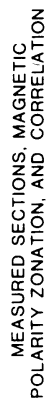

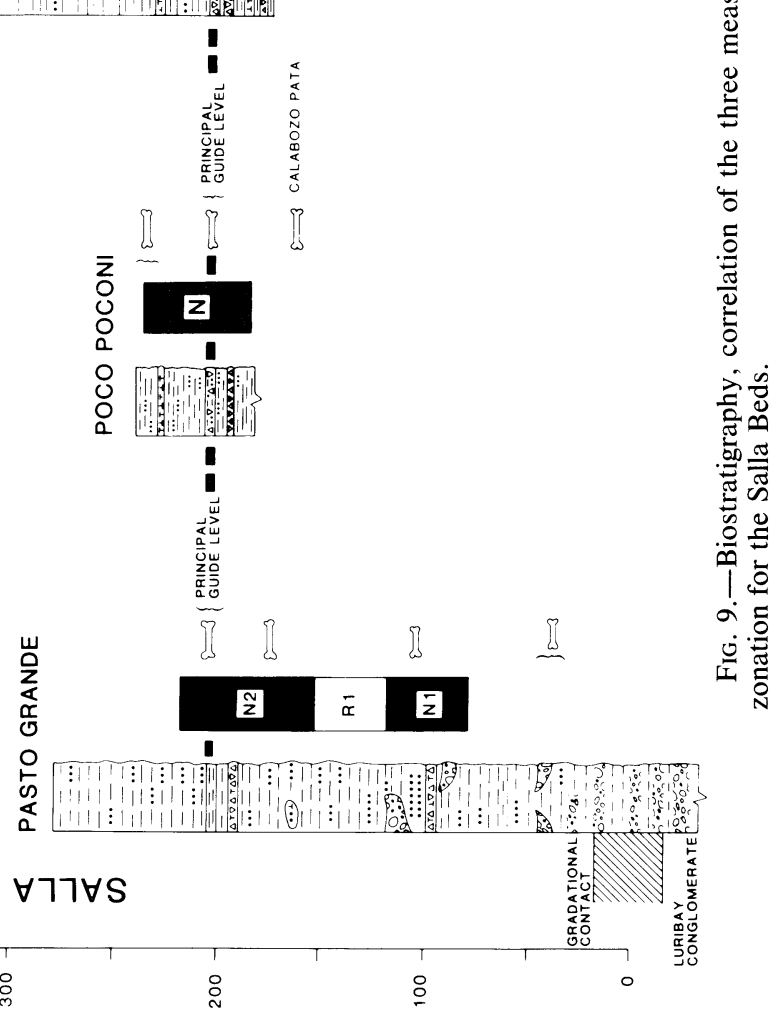




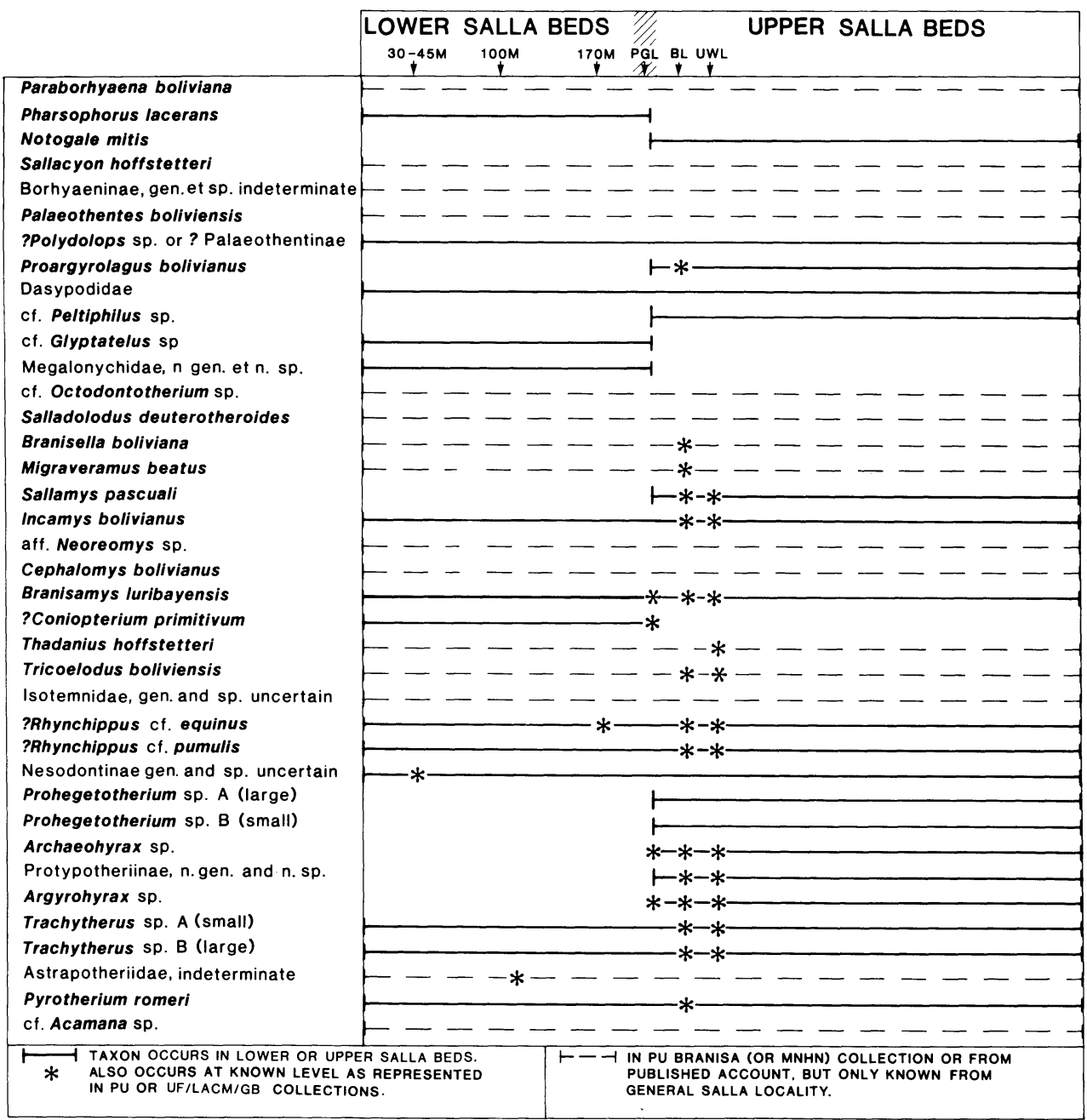

FIG. 10.-Preliminary biostratigraphic distribution of mammalian taxa in the Salla Beds based on study of the UF/LACM/GB and PU collections and published accounts (see references cited in text). The arbitrary division of the lower and upper Salla Beds (with the transition at the Principal Guide Level) allows recognition of many of Branisa's localities and integration of many of the PU specimens into this scheme.

Marshall (1978) recognized this species from Salla based on two specimens, PU 20551 and PU 21865 (also see Petter and Hoffstetter 1983). Branisa's field notes indicate that these specimens were collected from his locality $\mathrm{V}$ $12 \mathrm{~A}$ in the lower part of the section. Pharsophorus lacerans is also known from the Deseadan Cabeza Blanca local fauna of Patagonia, Argentina.

Notogale mitis. - This small marsupial is represented by about 15 specimens from Salla preserved in the PU, MNHP and GEOBOL collections (Patterson and Marshall 1978; Villarroel and Marshall 1982; Petter and Hoffstetter 1983). Unfortunately, there are no specific locality data associated with any of the specimens. Notogale mitis is also known from the Deseadan Cabeza Blanca local fauna in Patagonia, Argentina.

Sallacyon hoffstetteri.-This species was described from three specimens from Salla, GB 539 (Villarroel and Marshall 1982) and MNHP SAL 92 and 93 (junior synonym, "Andinogale sallensis"; Hoffstetter and Petter 1983). It has recently been reported from La Flecha, Argentina (Marshall et al. 1984). The Salla sample is of unknown provenience. Villarroel and Marshall (1982) suggest Sallacyon hoffstetteri as the probable ancestor of the later Tertiary borhyaenids Perathereutes and (or) Sipalocyon.

Borhyaeninae, gen. et sp. indet.- 


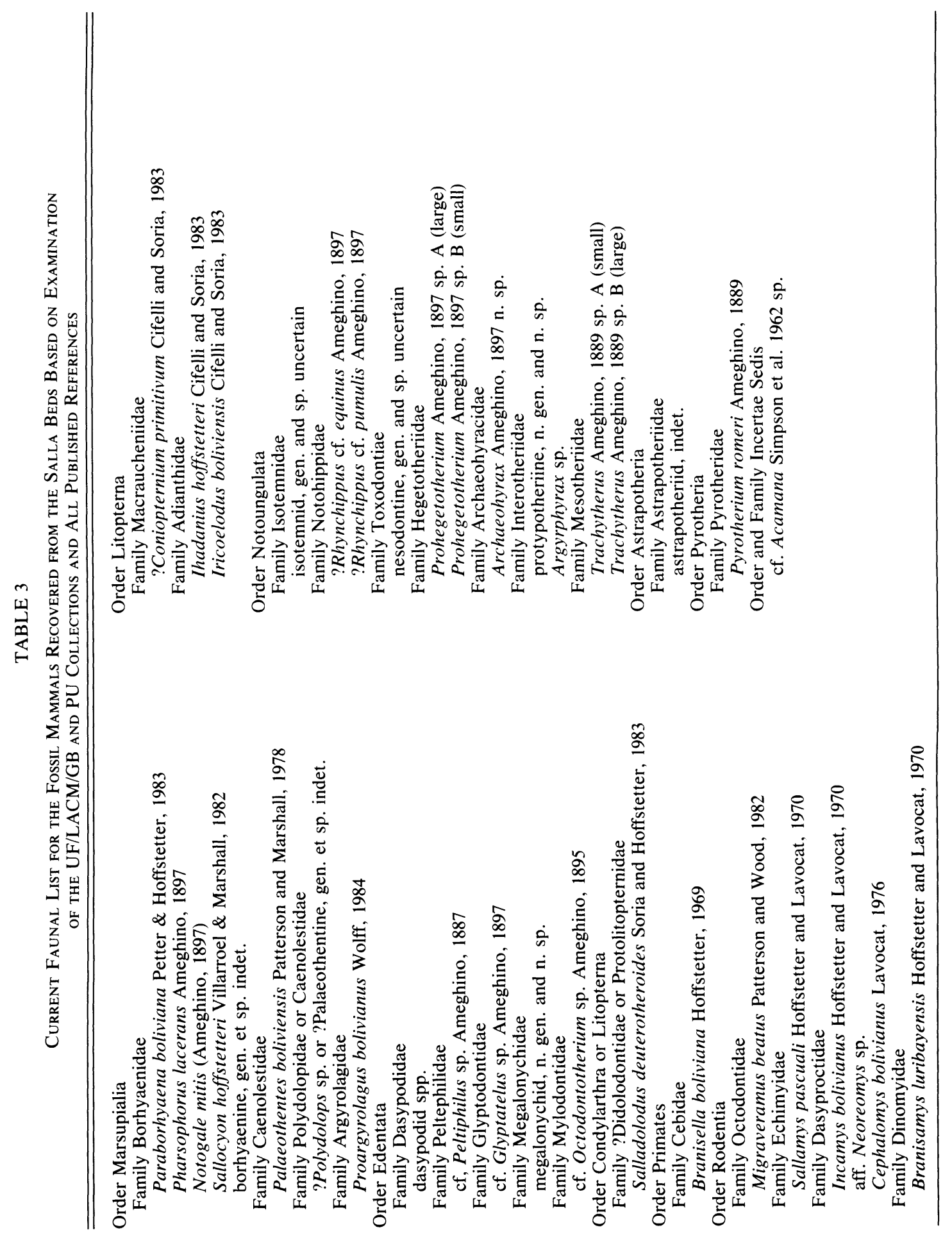


Patterson and Marshall (1978) originally recognized this taxon as Proborhyaena gigantea based on two specimens from Salla, PU 21866 and PU 21922 (no specific locality data available). However, Petter and Hoffstetter (1983) concluded that the assignment to that species (as described from Patagonia by Patterson and Marshall 1978) was unconvincing. Given the poorly preserved material from Salla, we follow this more recent interpretation. Additional material must be found in order to elucidate the taxonomic and biostratigraphic utility of this species.

Palaeothentes boliviensis.-Patterson and Marshall (1978, also see Villarroel and Marshall 1982) originally described this species based on material from Salla. It recently has been reported from La Flecha, Argentina (Marshall et al. 1984). The hypodigm from Salla consists of two specimens, PU 21977 and GB SAL 621, from, respectively, Branisa's V-2 locality and Tapial Pampa. With regard to the biochronology, Patterson and Marshall (1978, p. 45) state that: "Palaeothentes boliviensis is slightly smaller than, but is structurally similar to $P$. chubutensis from Cabeza Blanca. The possibility exists that $P$. boliviensis is ancestral to $P$. chubutensis, making the fauna from Cabeza Blanca slightly later than that of Salla."

?Polydolops sp. or ?Palaeothentinae, gen. et sp. indet.-Patterson and Marshall (1978) and Marshall (1982) described ? Polydolops sp. from Salla based on a single fragmentary lower jaw, PU 21998, collected by Branisa from his locality V12F (in the lower part of the section). Villarroel and Marshall (1982) described the presence of ?Palaeothentinae gen. et sp. indet., GB 088, from the "nivel superior" at Kolla Huichinca (a probable equivalent of our Upper White Level). Those authors suggested that PU 21998 may actually represent the lower dentition of an indeterminate palaeothentine. The exact taxonomic assignment and biostratigraphic utility of this marsupial must await the collection of more specimens.

Proargyrolagus bolivianus.-Wolff (1984) described this new species based on two incomplete rami containing teeth, UF 27895 and UF 27896, from the Branisella Level. This is a rather surprising discovery for a Deseadan fauna because previously the family
Argyrolagidae had its earliest occurrence in Huayquerian (late Miocene) deposits from Argentina. The phylogenetic position of argyrolagids is somewhat problematical, although most workers follow Simpson (1970) in referring the Argyrolagidae to the Marsupialia.

\section{EDENTATA:}

General Comments.-The edentates represent one of the major unstudied groups at Salla. Our taxonomic and biostratigraphic observations on the Salla forms are therefore preliminary.

Dasypodidae.-Several jaws and many dermal scutes occur from several localities in the Salla Beds. Hoffstetter $(1968,1976)$ lists the possibility of at least three genera of dasypodids including "Prozaedius," Proeutatus, and an undescribed form.

Cf. Peltephilus sp.-A small sample (including a relatively well preserved skull) is represented in the PU collection. These occurrences are from Branisa's V-2 locality in the upper part of the section.

Cf. Glyptatelus sp.-A single specimen, PU 22164, consisting of a caudal fragment with vertebrae and dermal scutes is known from the Branisa's V-12 locality in the lower part of the section.

Megalonychidae $n$. gen. et n. sp.-A single lower jaw of an undescribed taxon, PU 20552, is represented from Branisa's V-12 locality. This very interesting specimen, primitive in many aspects, is currently under study by Dr. George F. Engelmann at the University of Nebraska, Omaha.

Cf. Octodontotherium sp.-A single lower jaw with two posterior teeth, PU 21972, is referable to this genus from Salla with, however, no specific locality data. Marshall et al. (1983) consider this genus to be a Deseadan index taxon.

\section{PRIMATES:}

Branisella boliviana.-Hoffstetter (1969) described this genus and species of ceboid monkey from Salla based on a partial left maxilla containing well-preserved $\mathrm{P}^{4}-\mathrm{M}^{2}$. Since the original description three other specimens have come to light: a fragmentary lower jaw with $\mathrm{M}^{2}$, PU 21861, with no specific locality data, a partial right maxilla, UF 27887, and a fragmentary right mandible, UF 27888 (Wolff 1985). The UF specimens 
were both collected from the Branisella Level at 230-240 m (see fig. 2E). Branisella boliviana is known only from Salla and remains to date the only known Deseadan primate. This taxon has generated much discussion concerning the timing of dispersal of platyrrhine primates into South America and the phylogenetic origins of ceboid monkeys (e.g., Ciochon and Chiarelli 1981).

\section{?CONDYLARTHRA OR LITOPTERNA:}

Salladolodus deuterotheroides.-Soria and Hoffstetter (1983) describe this new genus and species based on two isolated teeth (one upper and one lower, MNHN SAL 266 and 267 , respectively) from the general Salla area (no specific locality known). They refer this taxon to the Order Condylarthra, Family Didolodontidae, and assert that it is intermediate in morphology between that group and the prototheriid litopterns. However, this poses a number of character conflicts at various levels within both groups. The assignment of Salladolodus to the early Tertiary litoptern family Protolipternidae cannot be ruled out because the dentition of that family is didolodont-like (i.e., primitive). Neither family is otherwise known from the Deseadan; protolitopternids are known only from the Riochican and possibly the Casamayoran (Cifelli 1985a); didolodonts are primarily known from these early Tertiary faunas but persisted into the Friasian in the form of Megadolodus (McKenna 1956). Depending on its affinities, Salladolodus may represent a late survivor of an early Tertiary group or a primitive member of the advanced litoptern family Proterotheriidae. It should also be noted here that several fragmentary, proterotheriid-like lower molars are present in the Salla collections. These are of appropriate size for Salladolodus. If these specimens do indeed belong to this genus then its proterotheriid affinities are strengthened and the phylogeny of advanced litopterns needs to be reconsidered.

\section{RODENTIA:}

Migraveramus beatus.-Patterson and Wood (1982) described this new species of octodontid based on the one specimen available to them, PU 21948, from the general Salla area. Several additional specimens in the UF/LACM/GB collection of this rare taxon are represented from the upper part of the Salla Beds. Patterson and Wood (1982, p. 382) state that: "We conclude that the octodontids are the most primitive of the Deseadan rodents, and the nearest known approach to the ancestral condition is represented by Migraveramus."

Sallamys pascuali.-Hoffstetter and Lavocat (1970) described this echimyid from the general Salla area. The PU collection consists of 12 specimens referable to this taxon from Branisa's Upper White Level and general Salla area (Patterson and Wood 1982). The $\mathrm{UF} / \mathrm{LACM} / \mathrm{GB}$ collection contains the largest sample of Sallamys from several stratigraphic horizons (fig. 10). No specimens of Sallamys are known to occur from the lower part of the section.

Incamys bolivianus.-Patterson and Wood (1982) describe the largest known sample (ca. 90 dentitions) of this species which occurs in several horizons in the upper part of the section. Of this sample, about one-third was collected from the Upper White Level. The UF/ LACM/GB specimens come from both the Branisella and Upper White levels. A single specimen, PU 21970, was supposedly collected from Branisa's V-12 locality. If the field data are correct, then this represents the only known occurrence of this rodent from the lower part of the Salla Beds.

Aff. Neoreomys sp.-Patterson and Wood (1982) state that a single specimen, MNHN SAL 118, previously referred to Incamys bolivianus (Lavocat 1976), represents a new dasyproctid genus close to Neoreomys. This specimen was collected from the general Salla area (no specific locality known). No other specimens referable to this taxon are as yet recognized from either the $\mathrm{PU}$ or $\mathrm{UF} /$ LACM/GB collections.

Cephalomys bolivianus._Lavocat (1976) described the presence of this dasyproctid from the general Salla area based on a single specimen, MNHN SAL 164. No other specimens referable to this taxon have been recognized from either the PU or UF/LACM/GB collections.

Branisamys luribayensis._-Based on specimens from Salla, Hoffstetter and Lavocat (1970) described this large rodent, which probably has affinities with the Dinomyidae. A moderate-sized sample of this species is represented in the PU collection (Patterson 
and Wood 1982) from the upper fossiliferous portions of the Salla Beds. Numerous specimens of B. luribayensis in the UF/LACM/ GB collection come from the same part of the section (including the Branisella Level), and recent field work in September, 1984 indicates that, although rare, this genus also occurs from the lower part of the section (Quebrada Chala Jahuira). Hartenberger (1975) described Villarroelomys bolivianus from Salla based on a single specimen, GB 014 . He stated that this form was a member of the Hydrochoeridae based on dental pattern. However, subsequent workers (Lavocat 1976; Patterson and Wood 1982) concluded that GB 014 represents a deciduous premolar of Branisamys luribayensis.

General Comments on Salla Rodents.The Salla rodents are of prime importance to an understanding of the origin of the Caviomorpha, and, as such, these mammals have been extensively studied (references cited above). Based on the several hundred relevant specimens of known stratigraphic context, rodents seem to be rare in the lower part of the Salla Beds. They first appear in abundance at Calabozo Pata about $45 \mathrm{~m}$ below the base of the Principal Guide Level.

The composition of the Salla rodent fauna is strikingly different from that of the Deseadan of Argentina both in terms of taxonomy and relative abundances (Wood and Patterson 1959; Patterson and Wood 1982). In general, the Salla rodents are less hyposodont than those from the Deseadan of Argentina. Hoffstetter and Lavocat (1970) suggest that these are principally ecological differences. Hartenberger (1975) suggested that the stage of evolution of the Salla rodents was intermediate between Scarritt Pocket (also see Wood and Patterson 1959) and the typical Deseadan La Flecha and Cabeza Blanca localities of Patagonia. As mentioned above, Patterson and Wood (1982) suggest that Migraveramus from Salla is primitive and very close to the ancestry of other Caviomorpha.

\section{LITOPTERNA:}

?Coniopterium primitivum.-Cifelli and Soria $(1983 a)$ described this primitive macraucheniid litoptern based on material in the PU and MNHN Salla collections. Additional undescribed specimens occur in the UF/ LACM/GB collection. So far as is known, this relatively rare species is recorded from the Salla general locality and from V-12, the lower part of the section. Two morphs of ?C. primitivum are known from Salla and may be specifically distinct (Cifelli and Soria 1983a). It is noteworthy that the single specimen assignable to stratigraphic level (V-12) pertains to the more primitive of the two morphs. In its known morphology, ?C. primitivum, which is only known from Salla, is more primitive than $C$. andinum from Patagonia.

Thadanius hoffstetteri.-Cifelli and Soria $(1983 b)$ originally described this small, rare adianthid litoptern based on material in the PU collection from Salla (specific locality not known). Specimens of $T$. hoffstetteri in the UF/LACM/GB collection are known to occur from the Branisella level. This species is only known from Salla; it is the most primitive of undoubted, i.e., Deseadan and later, Adianthidae (Cifelli and Soria 1983b). Hoffstetter (1976) listed the similar-sized Deseadan adianthid Proadianthus among the Salla fauna; however in light of recent studies it is probably $T$. hoffstetteri.

Tricoelodus boliviensis.-Cifelli and Soria (1983a) described this pygmy litoptern based on material in the PU collection from Salla (specific locality not known). Additional undescribed specimens from the Branisella and Upper White levels are represented in the UF/LACM/GB collection. Tricoelodus boliviensis is more primitive than the also rare but much better known type species, $T$. bicuspidatus, from Patagonia (Cifelli and Soria 1983b).

\section{NOTOUNGULATA:}

Isotemnidae, genus and species undetermined.-Several isolated upper and lower molars from the PU and UF/LACM/GB collections are referable to the Isotemnidae. The PU specimens are only known from the general Salla area and those from the UF/ $\mathrm{LACM} / \mathrm{GB}$ collection are from the lower part of the Salla Beds. Affinities within the Isotemnidae remain to be determined. Hoffstetter (1976) referred materials of probably the same taxon to Henricofilholia, species of which are synonymous with various species of Leontinia and Ancylocoelus, large and small (respectively) leontiniids typical of Deseadan local faunas of Patagonia (Cifelli, pers. obs., and Patterson, unpub.). The 
Isotemnidae, the most primitive notoungulate family above the notioprogonian level (Simpson 1967) and very abundant in early Tertiary faunas, make their last appearance in the Deseadan. There they are represented by Pleurocoelodon and the possibly synonymous Trimerostephanos. (McKenna, 1956, referred a specimen from the Friasian of Colombia to the family, but the specimen is too fragmentary for confident placement.) Remains of Deseadan isotemnids are rare; in Argentina they are known from La Flecha (the type Deseadan) and Cabeza Blanca.

Cf. Rhynchippus.-Two notohippid species, differing principally in size, are present at Salla and are tentatively referred to the species Rhynchippus equinus and $R$. pumilus, otherwise known from Patagonia. These taxa are represented in both the PU and UF/ $\mathrm{LACM} / \mathrm{GB}$ collections and they occur in numerous horizons in the Salla Beds. As with most Deseadan local faunas, notohippid materials are rather common at Salla, with the large species being the more abundant of the two. Notohippids are most abundant and diverse during the Deseadan; perhaps four valid genera of Rhynchippinae and two of Notohippinae are present in local faunas of that age in Patagonia. The primitive subfamily Rhynchippinae is not recorded after the Deseadan.

Nesodontinae, genus and species uncertain.-This toxodontid is represented by fragmentary specimens known from several horizons within the Salla Beds. These may be referable to the Deseadan and Colhuehuapian genus Proadinotherium as indicated by Hoffstetter (1976), but we are at present unable to characterize nesodontine genera on the basis of isolated molars. Nesodontine toxodontids are among the many advanced notoungulate groups that make their first appearance in the Deseadan, and their remains are found in moderate abundance at most localities of this age in Argentina.

Prohegetotherium spp.-The large series of relatively complete specimens of this genus in the PU collection sort into two size groups, here tentatively recognized as distinct species. (Although the extent of sexual dimorphism in notoungulates remains to be properly assessed, this seems unlikely in the present case. In addition to size differences, the taxa differ in other morphological charac- ters and in relative abundance.) The less complete UF/LACM/GB materials have not yet been sorted; however, at least one of these forms occurs in the Branisella and Upper White levels. The larger of the species represented in the PU collection, comparable in size to $P$. sculptum (a typical species from Patagonia), is the more abundant of the two, being represented by about 140 specimens. The smaller species is known from about 30 specimens. With a few dubious exceptions, the advanced notoungulate family Hegetotheriidae is first recorded from the Divisadero Largo local fauna in the form of Ethegotherium (Simpson et al. 1962). In addition to Prohegetotherium, most Deseadan local faunas of Patagonia also include one or more members of the somewhat aberrant and strictly Deseadan hegetothere group which includes the possibly distinct genera Prosotherium and Propachyrucos. However, these are conspicuously absent at Salla.

Archaeohyrax sp.-An undescribed species of Archaeohyracidae is represented in the PU and UF/LACM/GB Salla collections. Archaeohyrax sp. is known to occur in the Principal Guide, Branisella, and Upper White levels. It is smaller than, but clearly a close ally of, the type species $A$. patagonicus from Cabeza Blanca, Chubut (Patterson and Cifelli, in prep.). This is by far the single most abundant species at Salla, being represented by more than 500 specimens in the PU and $\mathrm{UF} / \mathrm{LACM} / \mathrm{GB}$ collections. This abundance is startling in view of the scarcity of specimens pertaining to Deseadan and earlier members of this family in Patagonia.

Interatheriidae.-The Salla interatheres are here referred to two taxa, both belonging to the group including Protypotherium and allies (Cifelli 1985a) within the advanced interatheres, subfamily Interatheriinae. The larger and more abundant of the Salla species, probably a new genus, was referred by Hoffstetter $(1968,1976)$ to Plagiarthrus but differs from that genus and other Interatherium allies in the molarization of the posterior premolars. The smaller Salla species, considerably rarer, is probably referable to the Argyrohyrax, also known from Patagonia [including Progaleopithecus and possibly also Archaeophylus (Marshall et al. 1985)] although it is distinct from the species A. proavunculus). Both taxa are known to 
occur in the upper part of the Salla Beds as indicated by specimens in the PU and UF/ LACM/GB collections. Interatheriids are first known in the late Casamayoran (Cifelli 1985a) of Patagonia, but advanced forms, subfamily Interatheriinae, do not appear until the Deseadan, when they underwent an extensive radiation (Cifelli 1985b).

Trachytherus spp.-The Mesotheriidae are represented in the PU and UF/LACM/GB collections by two taxa that differ in size and several morphological features (such as the relative proportions of the anterior premolars). These taxa probably both occur throughout the section at Salla. These were previously referred to Trachytherus spegazzinianus and an undescribed genus (Hoffstetter 1976). Both are here more conservatively considered as undetermined species of Trachytherus pending detailed systemic studies. Trachytheriine mesotheriids, probably represented in the Deseadan of Argentina only by the type genus Trachytherus, are a rather rare but characteristic element of almost all Deseadan local faunas. The presence of two species at Salla, which are represented by rather complete and abundant remains, is unusual. Mesotheriids are first known to occur in the Divisadero Largo local fauna, represented by ?Trachytherus (Simpson et al. 1962). However, Cifelli (1985b) suggested that lower molars assigned to the Mustersan archaeohyracid Pseudhyrax eutrachytheroides may pertain to the family. Mesotheres are not encountered in subsequent faunas until the Friasian.

Astrapotheriidae, indeterminate.-Two fragmentary dentitions in the PU Salla collections are referable to this taxon, PU 22055 and 22192 (specific locality unknown). One astrapothere specimen in the UF collection, UF 68054, occurs from the lower Salla Beds equivalent at Quebrada Chala Jahuira. In contrast to their common occurrence in Deseadan local faunas from Argentina, astrapothere remains are rare at Salla.

Pyrotherium romeri.-MacFadden and Frailey (1984) refer the Salla pyrothere to the classic Deseadan species $P$. romeri. This taxon is fairly well represented by dental and postcranial remains, and it is known from several horizons within the Salla Beds (fig. 10). This genus is the principal guide taxon and original name bearer (Ameghino's "couches a Pyrotherium") of the Deseadan fauna in Argentina, although it may not extend into the latest part of this Land Mammal Age (Marshall et al. 1985).

Cf. Acamana sp.-One PU specimen, consisting of an edentulous premaxilla from an undetermined level in Salla, is tentatively referred to Acamana, otherwise known only from a single, similar specimen from the $\mathrm{Di}$ visadero Largo local fauna of Argentina (Simpson et al. 1962). Due to the fragmentary nature of the known specimens, the affinities of Acamana are problematical. McKenna (1981) suggested that it might be a trigonostylopid. The only known trigonostylopid skull with a rostrum, that of Eoastrapostylops riolorense, unfortunately was not figured by Soria and Powell (1982) in ventral view. Among South American fossil mammals, the specialized anterior dentition of Acamana is similar to Simpsonontus, a ?henricosborniid notoungulate known from the Riochican Mealla Formation of northwestern Argentina (Pascual et al. 1978). The Henricosborniidae, which includes the most primitive notoungulates, is restricted to the Riochican and Casamayoran and, with several dubious exceptions, is not encountered in Patagonia after the early Casamayoran (Cifelli 1985a).

SUMMARY:

The faunas from the Salla Beds seem to change in taxonomic composition about onethird of the way up the measured section at about the Principal Guide Level. Our preliminary assessments of these faunas are as follows (also see fig. 10):

Lower Salla Beds.-This part of the section is either pre-Deseadan (?Divisideran) or earliest Deseadan in age. The choice between these two possibilities depends on the definitions of (1) the Divisideran, which is either early Deseadan or latest pre-Deseadan (Simpson et al. 1962) or a Land Mammal Age distinct from the Deseadan (Pascual et al. $1965,1966)$ and (2) the paleontological criteria used to define the base of the Deseadan. Regardless of the ultimate definitions of these biochronological units (which must come from the Argentine sequence), the lower Salla Beds have some notable biostratigraphic characteristics.

Among the edentates, an undescribed primitive taxon of Megalonychidae is only 
known from Branisa's V-12 locality. Of the several hundred specimens of rodents collected from Salla, only a few (one of Incamys and several of Branisimys) occur within this part of the section. Trachytherus, which occurs in both the Divisideran and Deseadan of Argentina (Marshall et al. 1983) is known from this part of the Salla Beds. Pyrotherium, the principal index taxon to the Deseadan in Argentina, is known to occur here. Rhynchippus is very common in the lower Salla Beds. The rare astrapothere is only known to occur from near the base of the Salla Beds at Quebrada Chala Jahuira.

Upper Salla Beds.-The most dramatic difference between the lower and upper parts of the section is the very common occurrence of rodents in the upper Salla Beds. Another important occurrence in this zone is Branisella, which has received wide attention as the earliest ceboid primate (e.g., Ciochon and Chiarelli 1981). As was noted by Hoffstetter $(1968,1976)$, many of the remaining Salla mammals are characteristic Deseadan taxa. Of the generic list of Deseadan mammals that occur in Argentina (Marshall et al. 1983) Palaeothentes, Prohegetotherium, and Archaeohyrax seem to be restricted to the upper part of the Salla Beds. Trachytherus and Pyrotherium occur throughout the known fossiliferous portions of the Salla Beds.

It seems clear that the upper part of the Salla Beds is Deseadan in age. However, the temporal placement of the Salla fauna with respect to the local faunas of Deseadan age from Patagonia remains problematic. Some of the unusual features of the Salla fauna have been noted previously, with opinion being divided as to whether these differences are ecological (Patterson, in Patterson and Wood 1982; Hoffstetter and Lavocat 1970) or temporal (Wood, in Patterson and Wood 1982; Hartenburger 1975). The presence of primates, abundance of Trachytherus and Archaeohyrax, and the scarcity or absence of astrapotheriid, leontiniid, and toxodontid remains is regarded here to reflect ecological, or zoogeographic differences between Salla and the localities in Patagonia. The hegetotheres, interatheres, notohippids, and archaeohyracid are not, at the present state of knowledge, suggestive of a precise age (other than the fact that they are Deseadan).
Certain elements of the fauna, either by presence/absence, or stage of evolution, appear to reflect an age difference with respect to those of Patagonia. Acamana, the ?Polydolops/palaeothentine, isotemnid, Salladolodus, and Trachytherus belong to archaic groups not known from the late Deseadan Scarritt Pocket local fauna or (with one exception) later in the fossil record (Marshall et al. 1985). The litopterns, which have been compared closely with Argentine forms, include the most primitive members of their respective lineages (Thadanius hoffstetteri, Tricoelodus boliviensis, and ?Coniopternium primitivum). MacFadden and Frailey (1984) noted that Salla Pyrotherium romeri seems slightly smaller (and ?possibly more primitive) than this species as it is known from Argentina. These data suggest that Salla is slightly older than other local faunas of Deseadan age known from Argentina.

\section{CORRELATION TO THE TIME SCALE}

Three separate lines of evidence are used to correlate the Salla Beds to the standard magnetic polarity scale (MPTS). These include the following: (1) The stage of evolution of the fossil mammals, which indicate a probable early Deseadan age for the Salla Beds. Marshall et al. (1977) originally published K/ Ar dates for the Deseadan from Argentina of $35.4 \pm 0.4$ and $33.6 \pm 0.4 \mathrm{Ma}$. However, additional dates have become available since those were published (Marshall et al. 1983; Marshall et al. 1985) indicating: (a) that the original dates are probably several million years too old; (b) it is not certain if the dates published by Marshall et al. (1977) do, in fact, date the Land Mammal Age because no Deseadan fossil mammals are definitely recorded in direct stratigraphic context with respect to the basalts in question; and (c) volcanics interbedded with fossils at Scarritt Pocket, Argentina, which on faunal evidence appears to be slightly younger than typical Deseadan local faunas, yield $\mathrm{K} / \mathrm{Ar}$ dates in the 24-21 Ma range (Marshall et al. 1985).

2) A K/Ar date of $26.4 \pm 1.0$ Ma was produced from a tuff located at $195 \mathrm{~m}$ above the base (ca. $10 \mathrm{~m}$ below the Principal Guide Level) of the Salla section. This tuff directly underlies the main fossiliferous concentrations in the El Planimiento section. The fission track dates located much higher in the 
same section, although they are not used here in the correlation to the MPTS, suggest ages younger than the $\mathrm{K} / \mathrm{Ar}$ date. This age relationship is obviously concordant with the superpositional order of the relevant tuffaceous horizons.

3) The sequence and pattern of reversals for the Salla Beds is represented by 14 magnetic polarity zones (figs. 9, 11). Most of the reversals in the Salla Beds are concentrated in the lower two-thirds of the section, whereas the upper one-third is characterized by almost continuous reversed polarity (zones R6 and R7). This long period of reversed polarity imparts a relatively distinctive signature to the Salla magnetic polarity zonation.

Given items 1 and 2 above, we may infer that the Salla Beds should lie within the 20 to $30 \mathrm{Ma}$ range. Within this time period, a relatively long, reversed signature on the MPTS lies within the lower two-thirds of Chron C6 between 24 and $26 \mathrm{Ma}$. We assert that the long reversed polarity zone represented by Salla zones R6-R7 correlates to Chron 6 (fig. 11). Using this correlation as our principal anchor-point, figure 11 indicates our preferred correlation of the Salla magnetic polarity zonation with the MPTS. It should be noted that the details of the MPTS of Berggren et al. (1984) are at considerable variance with that of Mankinen and Dalrymple (1979) for this same time interval (fig. 11). Despite these complications, the correlation we propose in figure 11 seems correct and is corroborated by the data presented here (i.e., principally the $\mathrm{K} / \mathrm{Ar}$ date of $26.4 \pm 1.0 \mathrm{Ma}$ and the distinctive correlation between zones R6-R7 at Salla and C6 on the MPTS).

Therefore, our current data suggest that the Salla Beds span an interval from at least $28.5 \mathrm{Ma}$ to about $24 \mathrm{Ma}$ (fig. 11), i.e., from late Oligocene to early Miocene time. We reiterate that this is not a unique correlation to the MPTS; however, it is our preferred hypothesis based on the K/Ar date and the stage of mammalian evolution. As noted, the fission-track dates in the upper part of the section are ca. 2-3 m.y. younger than would be expected from this correlation. Recently we have further sampled relevant tuffaceous horizons for additional corroborative isotopic age determinations. Also, the complementary search for fossil mammals in the upper part of the El Planimiento section may elucidate the upper age and extent of the Deseadan Land Mammal Age as represented in the Salla Beds. The data and our chronological hypothesis presented here have significant ramifications with regard to the calibration of the Deseadan Land Mammal Age and associated paleontological hypotheses.

\section{CONCLUSIONS, SIGNIFICANCE AND DISCUSSION}

Deseadan Calibration.-The present study suggests a significant recalibration of this Land Mammal Age. Marshall et al. (1983; our fig. 12) indicate the Deseadan spanned a time from about 37 to $27 \mathrm{Ma}$, which made it the longest of the South American Land Mammal ages. The stage of evolution of the Salla Mammals and correlation to the time scale suggest that the basal Deseadan should be no older than ca. 27-28 Ma (our "preferred hypothesis" in fig. 12). The Salla Beds are of added importance because they appear to represent the earliest Deseadan, which is a period of time not recognized in Argentina. With the results from this study (along with those of Marshall et al. 1985), the temporal limits of the Deseadan must be revised significantly, i.e., shifted upwards by ca. 10 m.y. from early Oligocene to late Oligoceneearly Miocene.

Pascual et al. $(1965,1966)$ suggest that the Divisideran is a distinct, pre-Deseadan Land Mammal Age. In their primitive aspects, several elements of the lower Salla fauna are suggestive of "Divisideran" (fig. 12, alternate hypothesis). However, because the status and limits of the Divisideran are unclear, we provisionally place the entire Salla fauna in the Deseadan, because of its close affinities with local faunas of that age in Patagonia (fig. 12, preferred hypothesis). If the lower Salla Beds are indeed Divisideran, then there is no need to invoke a hiatus between this Land Mammal age and the Deseadan (fig. 12; Marshall et al. 1977). However, because the index taxon Pyrotherium occurs in the lower part of the section, we believe that our first hypothesis is correct. The ultimate resolution of this problem must come from a critical reassessment of the Divisideran and Deseadan ages as represented in Argentina.

Given the upward shift in the Deseadan, several other related considerations should be addressed: (1) The upper extent of the De- 


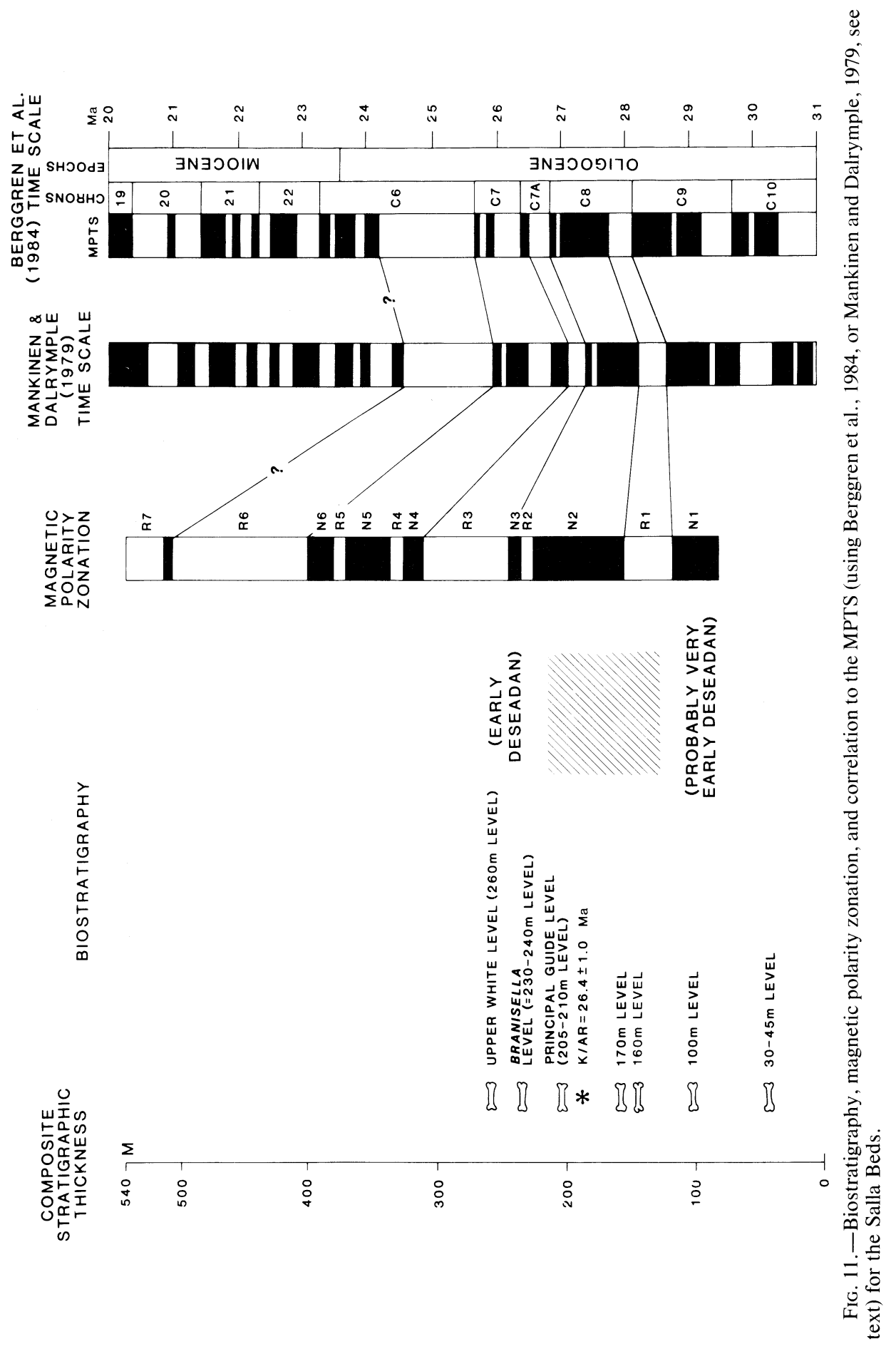




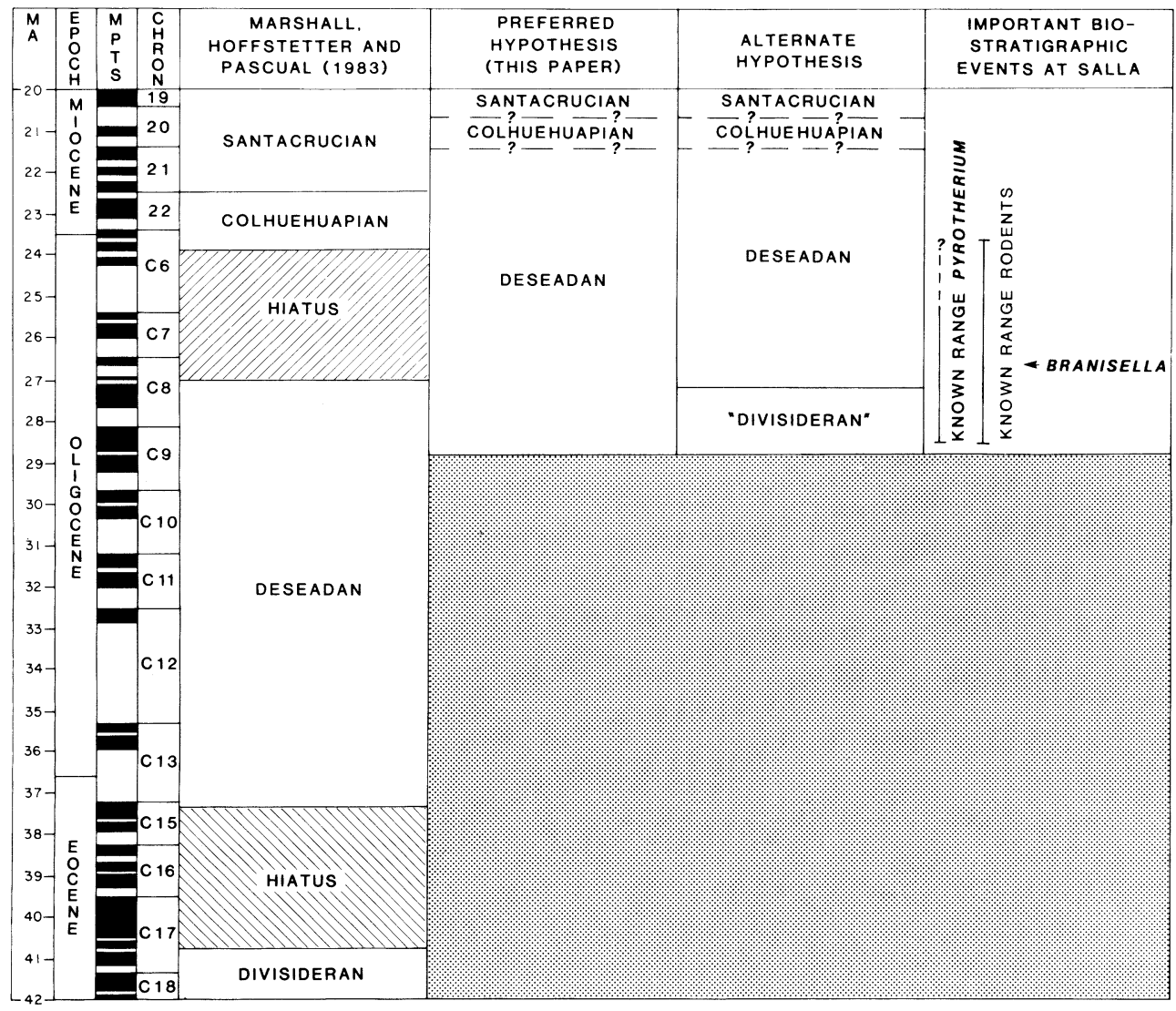

FIG. 12.-Comparisons of previous assessments of the age of the Deseadan Land Mammal age (Marshall et al. 1983) and the revised interpretations based on the present study. The dashed zones in the Marshall et al. (1983) correlation indicate postulated hiatuses.

seadan remains questionable as represented in the Salla sequence. Our present chronology suggests that known fossil levels extend upwards to Chron $\mathrm{C} 7$ at about $26 \mathrm{Ma}$; however, the top of the Salla Beds are at least as young as about $24 \mathrm{Ma}$. To date this part of the Salla Beds seems relatively unfossiliferous; it will not add to our knowledge of the later Deseadan until more fossil mammals and associated radiometric dates are collected.

Also, given the shift of the Deseadan upwards in time, what happens to the Colhuehuapian and Santacrucian Land Mammal Ages? The Colhuehuapian is usually stated to be late Oligocene with a significant hiatus between this Land Mammal Age and the Deseadan. The Colhuehuapian has been considered to be a very short Land Mammal Age of ca. 1-2 Ma duration (Marshall et al. 1983), although there are no radiometric (or paleomagnetic) data associated with known Colhuehuapian local faunas. The Santacru- cian is usually stated to be early Miocene with no significant hiatus between this Land Mammal Age and the Colhuehuapian. The Santacrucian has been considered as a relatively long Land Mammal Age with a duration of 6 m.y. from about 22 to $16 \mathrm{Ma}$. Marshall et al. (1977) list two $\mathrm{K} / \mathrm{Ar}$ dates associated with Santacrucian fossils of 21.7 $\pm 0.3 \mathrm{Ma}$ and $18.5 \pm 0.2 \mathrm{Ma}$. Work in progress (Marshall pers. comm.) indicates from a new suite of $\mathrm{K} / \mathrm{Ar}$ age determinations that the Santacrucian is certainly no older than ca. 21 $\mathrm{Ma}$, and it probably extends upward in time to ca. $15 \mathrm{Ma}$. Therefore our revised calibration of the Deseadan based on the Salla study is plausible.

Dispersal of Mammals into South America.-Since Ameghino's time, paleontologists studying Cenozoic mammals in South America have recognized the first appearance of rodents (and, more recently the primate Branisella from Salla) in the Desea- 
dan (see e.g., summary of the "Second Faunal Stratum" in Simpson 1980). This is generally accepted to represent allochthonous dispersal from Africa or North America (there is by no means a consensus on this subject, see, e.g., Ciochon and Chiarelli 1981). Until now, precise dating of these Deseadan events was unavailable. Because the Deseadan has been equated with "early Oligocene," and given the fact that the first set of published dates for this interval were $33.6 \pm 0.4$ and $35.4 \pm 0.4 \mathrm{Ma}$ (Marshall et al. 1977), these dispersal events were believed to have occurred at about 35 to $37 \mathrm{Ma}$. At Salla, rodents are known to occur throughout the fossiliferous horizons (although they are rare from the lower Salla Beds), which would indicate that they had arrived in South America before $28.5 \mathrm{Ma}$. The known stratigraphic occurrence of Branisella is $27 \mathrm{Ma}$. These new data place revised constraints on the potential timing and origins of these groups that could be $10 \mathrm{~m} . \mathrm{y}$. later than has been previously believed. So far as is known, our data suggest that the base of the "Second Faunal Stratum" could be as young as late (not early) Oligocene. This revised chronology should have significant ramifications with re- spect to future hypotheses of the timing and origin of South American rodents and primates.

ACKNOWLEdgments.-We thank Carlos Villarroel, Ronald G. Wolff, Carl David Frailey, and Annalisa Berta for their help in the field. Special thanks goes to Carlos Villarroel for his insight on the geology of Salla. Leonardo Branisa, John J. Flynn, Robert Hoffstetter, Larry G. Marshall, Steven R. May, S. David Webb, and A. E. Wood provided helpful comments that improved the manuscript. Dr. Donald Baird allowed us to study the PU Salla collection. Funds to defray field expenses for the PU Branisa Collection were provided by the Gordon Barbour bequest. Dr. A. E. Wood and Gary S. Morgan provided identifications for the rodents. This research was made possible through the funds and logistic support provided by the University of Florida, LACM, GEOBOL, and the U.S. National Science Foundation Grants DEB 79-05861 and EAR 8318903. Special thanks are extended to Ing. Raul Carrasco of GEOBOL for his support during this project. This report is University of Florida Contribution to Vertebrate Paleontology number 240.

\section{REFERENCES CITED}

Ahlfeld, F., and Branisa, L., 1960, Geología de Bolivia: La Paz, Instituto Boliviano del Petroleo, 245 p.

Ameghino, F., 1897, Mammifères crétacés de l'Argentine. (Deuxième contribution à la connaissance de la faune mammalogique des couches à Pyrotherium): Bol. Inst. Geogr. Argentina, Buenos Aires, v. 18, p. 406-429, 431521 .

Berggren, W. A.; Kent, D. V.; Flynn, J. J.; and Van Couvering, J. A., 1984, Cenozoic Geochronology: in press.

Bond, M., and Pascual, R., 1983, Nuevos y elocuentes restos craneanos de Proborhyaena gigantea Ameghino, 1877 (Marsupialia, Borhyaenidae, Proborhyaeninae) de la edad Deseadense. Un ejemplo de coevolucíon: Ameghiniana, v. 20, 47-60.

Cifelli, R. L., 1985a, Biostratigraphy of the Casamayoran, early Eocene, of Patagonia: Amer. Mus. Novitates, in press.

$1985 b$, South American ungulate evolution and extinction, in The Great American Interchange: Webb, S. D., and Stehli, F., eds. New York, Plenum Press, in press.

$\longrightarrow$, and Soria, M. F., 1983a, Notes on Deseadan Macraucheniidae: Ameghiniana, v. 20, p. 141-153. $\longrightarrow$, and $-1983 b$, Systematics of the Adianthidae (Litopterna, Mammalia): Amer. Mus. Novitates, v. 2171, p. 1-25.

Ciochon, R. L., and Chiarelli, A. B., 1981, Evolutionary biology of the New World monkeys and continental drift: New York, Plenum Press, $528 \mathrm{p}$.

Fisher, R. A., 1953, Dispersion on a sphere: Proc. Royal Soc. (London), Series A, v. 217, p. 295305.

Gleadow, A. J. W.; Hurford, A. J.; and Quaife, R. D., 1976, Fission track dating of zircon, improved etching techniques: Earth Planet. Sci. Letters, v. 33, p. 273-276.

Goree, W. S., and Fuller, M., 1976, Magnetometers using RF-driven SQUIDS and their applications in rock magnetism and paleomagnetism: Rev. Geophysics Space Physics, v. 14, p. 591608.

Hartenberger, J. L., 1975, Nouvelles découvertes de Rongeurs dans le Déséadien (Oligocène inférieur) del Salla Luribay (Bolivie): Comptes Rendus Acad. Sci., v. 280, p. 427-430.

Hayashida, A.; Rodrigo, L. A.; and SaAvedra, A., 1984, Fission track dating and paleomagnetic study of the Cenozoic continental deposits at Salla, Bolivian Andes: Kyoto Univ. Overseas Res. Repts. of New World Monkeys, v. 4, p. 89 94. 
Hoffstetter, R., 1968, Un gisement de mammifères déséadiens (Oligocène inférieur) en Bolivie: Comptes Rendus Acad. Sci., v. 267, p. 1095-1097.

1969, Un primate de l'Oligocène intérieur sud-american: Branisella boliviana gen. et sp. nov.: Comptes Rendus Acad. Sci., v. 269, p. 434-437.

_ 1976, Rongeurs caviomorphes de l'Oligocene de Bolivie: Palaeovertebrata, v. 7, p. 1-14.

-, and Lavocat, R., 1970, Découverte dans le Déséadien de Bolivie des genres pentalophodontes appuyant les affinities africaines des rongeurs Caviomorphes: Comptes Rendus Acad. Sci., v. 271, p. 172-175.

-; Martinez, R.; Matteur, M.; and Tomasi, P., 1971, Lacayani, un nouveau gisement bolivien de mammifères déséadiens (Oligocène inférieur): Comptes Rendus Acad. Sci., v. 273, p. 2215-2218.

- , and Petrer, G., 1983, Paraborhyaena boliviana et Andinogale sallensis, deux Marsupiaux (Borhyaenidae) nouveaux du Déséadien (Oligocène inférieur) de Salla (Bolivie): Comptes Rendus Acad. Sci., v. 296, p. 205-208.

Irving, E., 1964, Paleomagnetism and its applications to geological and geophysical problems: New York, Wiley, 399 p.

Johnson, N. M., and McGee, V. E., 1983, Magnetic polarity stratigraphy: stochastic properties of data, sampling problems, and the evaluation of interpretations: Jour. Geophys. Res., v. 88, p. 1213-1221.

Lavocat, R., 1976, Rongeurs caviomorphes de l'Oligocène de Bolivie. II. Rongeurs du Bassin Déséadien de Salla-Luribay: Palaeovertebrata, v. 7, p. 15-90.

MacFadden, B. J., and Frailey, C. D., 1984, Pyrotherium, a large enigmatic ungulate (Mammalia, Incertae Sedis) from the Deseadan (Oligocene) of Salla, Bolivia: Palaeontology, v. 27, p. 867-874.

Mankinen, E. A., and Dalrymple, G. B., 1979, Revised Geomagnetic Polarity time scale for the interval 0-5 Ma: Jour. Geophys. Res., v. 84, p. 615-626.

Marshall, L. G., 1982, Systematics of the extinct South American marsupial family Polydolopidae: Fieldiana Geology, new series, v. 12, p. $1-109$.

-; Cifelli, R. L.; Drake, R. E.; and Curtis, G. H., 1985, Geology, geochronology, and vertebrate paleontology of the Tapera de López and Scarritt Pocket, Chubut Province, Argentina: Jour. Paléont., in press.

- ; DE Muizon, C.; and Hoffstetter, R., 1984, Fossil Marsupialia in the Muséum national d'Histoire naturelle collected by André Tournouër from Patagonia, southern Argentina: Bull. Mus. Nat. D'Hist. Natur., Paris, v. 6, p. 33-58.

-; Hoffstetter, R.; and Pascual, R., 1983, Mammals and stratigraphy: Geochronology of the continental mammal-bearing Tertiary of South America: Palaeovertebrata, Mémoire Extraordinaire, p. 1-93.

-; Pascual, R.; Curtis, G. H.; and Drake,
R. E., 1977, South American geochronology: Radiometric time scale for middle to late Tertiary mammal-bearing horizons in Patagonia: Science, v. 195, p. 1325-1328.

Martinez, C., and Tomasi, P., 1978, Carte structurale des Andes Septentrionales de Bolivie a 1/ 1,000,000: Office de la Réchèrche Scientifique et Technique Outre-Mer, Notice Explicative (map), v. 77, 48 p.

McElhinny, M. W., 1973, Palaeomagnetism and plate tectonics: Cambridge, University Press, $357 \mathrm{p}$.

McKenna, M. C., 1956, Survival of primitive notoungulates and condylarths into the Miocene of Colombia; Am. Jour. Sci., v. 254, p. 736-743.

1981, Early history and biogeography of South America's extinct land mammals, in Ciochon, R. L., and Chairelli, A. B., eds., Evolutionary Biology of New World Monkeys and Continental Drift: New York, Plenum Press, p. 49-77.

NaESER, C. W., 1979, Fission track dating and geologic annealing of fission tracks, in JAGER, E., and Hunziker, J. L., eds. Lectures in Isotope Geology: Berlin, Springer-Verlag, p. 154-169.

Opdyke, N. D.; LindSAy, E. H.; Johnson, N. M.; and Downs, T., 1977, The paleomagnetism and magnetic polarity stratigraphy of the mammalbearing section of Anza Borrego State Park, California: Quat. Res., v. 7, p. 316-329.

Pascual, R. E.; Ortega Hinojosa, E. J.; Gondar, D.; and Tonni, E., 1965, Las edades del Cenozoico mamífero de la Argentina, con especial atención a aquellas del territorio Bonaerense: An. Com. Invest. Cien. Buenos Aires, v. 6, p. 165-193.

- - ; Gondar, D.; and Tonni, E., 1966, Paleontografía Bonaerense: Fasc. IV. Vertebrata. Com. Invest. Cient. Buenos Aires, p. 1202.

-; Vucetich, M. G.; and Fernandez, J., 1978, Los primeros mamíferos (Notoungulata, Henricosborniidae) de la Formación Mealla (Grupo Salta, Subgrupo Santa Barbara), sus implicancias filogéticas, taxonómicas y cronológicas: Ameghiniana, v. 15, p. 366-390.

Patterson, B., and Cifelli, R. L. The Deseadan Archaeohyracidae: in prep

- and Marshall, L. G., 1978, The Deseadan, early Oligocene, Marsupialia of South America: Fieldiana Geology, v. 41, p. 37-100. , and Pascual, R. E., 1972, The fossil mammal fauna of South America, in KeAst, A., ERK, F. C., and Glass, B., eds., Evolution, Mammals, and Southern Continents: Albany, State Univ. New York Press, p. 247-309.

, and Wood, A. E., 1982, Rodents from the Deseadan Oligocene of Bolivia and the relationships of the Caviomorpha: Bull. Mus. Comp. Zool., v. 149, p. 371-543

Petter, G., and Hoffstetter, L., 1983, Les marsupiaux du Déséadien (Oligocène inférieur) de Salla, Bolivia: Ann. Paleont., v. 69, p. 175-234.

SANJinés-S, G., and Jiménez-M, F., 1978, Comunicacíon preliminar acerca de la presencia de fósiles vertebrados en la Formación Petaca del 
area de Santa Cruz: Yacimientos Petrolíferas Fisicas Boliviano Revista Téchnica, Pub. Espec., v. 4, p. 147-156.

Simpson, G. G., 1967, The beginning of the Age of Mammals in South America: Bull. Amer. Mus. Nat. Hist.: v. 137, p. 1-260.

1970, The Argyrolagidae, extinct South American marsupials: Bull. Mus. Comp. Zool., v. 139 , p. 1-86.

1980, Splendid Isolation: The Curious History of South American Mammals: New Haven, Yale Univ. Press, 266 p.

; Minoprio, J. L.; and Patterson, B., 1962, The mammalian fauna of the Divisadero Largo Formation, Mendoza, Argentina: Bull. Mus. Comp. Zool., v. 127, p. 239-293.

Soria, M. F., and Powell, J., 1982, Un primitivo Astrapotheria (Mammalia) y la edad de la Formación Río Loro, Provincia de Tucumán, República Argentina: Ameghiniana, v. 18, p. 155168. and Hoffstetter, R., 1983, Presence d'un Condylarthre (Salladolodus deuterotherioides gen. et. sp. nov.) dans le Déséadien (Oligocène inférieur) de Salla, Bolivie: Comptes Rendus Acad. Sci., v. 297, p. 549-552.

Villarroel, C., and Marshall, L. G., 1982, Geology of the Deseadan (early Oligocene) age Estratos Salla in the Salla-Luribay basin, Bolivia, with description of new Marsupialia: Géobios, Mem. Spec. 6, p. 201-211.

WolfF, R. G., 1984, New early Oligocene Argyrolagidae (Mammalia, Marsupialia) from Salla, Bolivia: Jour. Vert. Paleont., v. 4, p. 108-113. 1985, New specimens of the primate Branisella boliviana from the early Oligocene of Salla, Bolivia: Jour. Vert. Paleont., v. 4, p. 570-574.

Wood, A. E., and Patterson, B., 1959, The rodents of the Deseadan Oligocene of Patagonia and the beginnings of South American rodent evolution: Bull. Mus. Comp. Zool., v. 120, p. 279-428. 